This item was submitted to Loughborough's Research Repository by the author.

Items in Figshare are protected by copyright, with all rights reserved, unless otherwise indicated.

\title{
Political and institutional determinants of credit booms
}

PLEASE CITE THE PUBLISHED VERSION

https://doi.org/10.1111/obes.12290

PUBLISHER

Wiley ( The Department of Economics, University of Oxford and John Wiley \& Sons Ltd.

\section{VERSION}

AM (Accepted Manuscript)

\section{PUBLISHER STATEMENT}

This is the peer reviewed version of the following article: CASTRO, V. and MARTINS, R., 2018. Political and institutional determinants of credit booms. Oxford Bulletin of Economics and Statistics, 81 (5), pp.1144-1178, which has been published in final form at https://doi.org/10.1111/obes.12290. This article may be used for noncommercial purposes in accordance with Wiley Terms and Conditions for Use of Self-Archived Versions.

\section{LICENCE}

CC BY-NC-ND 4.0

\section{REPOSITORY RECORD}

Castro, Vitor, and Rodrigo Martins. 2019. "Political and Institutional Determinants of Credit Booms". figshare. https://hdl.handle.net/2134/36402. 


\title{
Political and institutional determinants of credit booms*
}

\author{
Vítor Castro* \\ Loughborough University and NIPE \\ Rodrigo Martins ^ \\ University of Coimbra and CeBER
}

\begin{abstract}
The literature that investigates credit booms has essentially focused on their economic determinants. This paper explores the importance of political conditionings and central bank independence and provides some striking findings on this matter. Estimating a fixed effects logit model over a panel of developed and developing countries for the period 1975q1-2016q4, we find that credit booms are less likely when right-wing parties are in office, especially in developing countries, and when there is political instability. However, they have not proven to depend on the electoral cycle. More independent Central Banks are also found to reduce the probability of credit booms. Moreover, they seem to be more likely to occur and spread within a monetary union.
\end{abstract}

Keywords: Credit booms; Logit model; Political cycles; Government ideology; Central Bank independence. JEL classification: C25, D72, E32, E51.

\footnotetext{
* The authors thank the two anonymous referees for their helpful comments and suggestions.

* School of Business and Economics, Loughborough University, Loughborough, Leicestershire LE11 3TU, UK. Economic Policies Research Unit (NIPE), University of Minho, Campus of Gualtar, 4710-057 Braga, Portugal.

Tel.: +44(0) 1509 222706; E-mail: v.m.q.castro@lboro.ac.uk

^Faculty of Economics, University of Coimbra, Av. Dias da Silva 165, 3004-512 Coimbra, Portugal. Centre for Business and Economics Research (CeBER), Av. Dias da Silva 165, 3004-512 Coimbra, Portugal. Tel.: +351239790543; E-mail: rodrigom@fe.uc.pt
} 


\section{Introduction}

The 2008/09 financial crisis renewed the interest of economists and politicians in understanding the role that credit surges play in the formation, dissemination, and intensification of economic shocks. This event and the economic recession that followed reminded us, once again, that sometimes the credit system is not merely a spreader of shocks that hit the economy as the traditional financial accelerator mechanism suggests - but it can be the source of the shock. In the previous decades, most economies experienced moments of rapid credit growth (or credit booms), some of them followed by financial crisis (Jordà et al., 2011). These events are far from being rare and since they have the potential to both harm and benefit the economy, it is of great importance for policymakers to better understand the forces behind them.

A significant body of research has tried to comprehend the economic determinants of abnormal credit growth and has successfully identified some relevant macroeconomic factors that are associated with the credit dynamics (Gourinchas et al. 2001; Barajas, et al., 2009; Arena et al., 2015; Dell'Ariccia et al., 2016; Meng and Gonzalez, 2017; Avdjiev et al., 2018). However, the strict focus on economic determinants, neglecting other potential drivers, is a shortcoming found in the literature. This paper contributes to the extant literature by establishing a theoretical framework for the linkage between political and institutional factors and credit dynamics and by empirically testing this connection. It investigates if an electoral cycle is present; if government ideology and overall political instability alter the ability of an economy to generate credit booms; and tackles the relationship between monetary policy and credit booms in a new perspective by analyzing the role of Central Bank independence and monetary unions. There are arguments to reasonably assume that all these aspects can actually be relevant and contribute to a better understanding of credit booms - we return to this subject in section 3 . 
Regarding the economic factors, our results suggest that if policymakers want to regulate credit surges they should pay close attention to the relative price of credit, economic growth and economic openness and exert control over the liquidity in the system. Results also show that some of the political and institutional factors are empirically relevant and robust to changes in the definition of credit booms. Although no evidence of an electoral cycle in credit booms is found, they have proven to be less likely in the presence of some types of political instability (higher government turnover and decreased government's ability to stay in office) and when right-wing parties are in office, especially in developing countries. Regarding the institutional framework for monetary authorities, we find that when a country's monetary policy is in the hands of a single regional monetary union this seems to constitute a big challenge for the monetary authority: credit booms have proven to be more likely in those economies and when the level of Central Bank independence is low. The economic conditionings and central bank independence matter significantly for both industrial and developing countries. However, the political factors seem to matter most for the group of developing countries.

The rest of the paper is organized as follows. Section 2 reviews the existing literature on credit booms. Section 3 discusses the role of the political environment and of Central bank independence. Section 4 describes the data and methodology. The empirical analysis and the discussion of the results are presented in Section 5. Finally, Section 6 concludes.

\section{Literature Review}

Banking crisis are often associated with excessive credit expansions (Jordà et al., 2011). As such, credit plays, not just the traditional positive role of supporting investment and economic growth, but also exhibits, under certain conditions, a malignant effect on the economy. What these conditions are and what drives credit expansions have been important topics of research in 
recent years. The literature has mainly tackled them from an empirical perspective ${ }^{1}$ and identified some key explanatory factors (see Mendoza and Terrones, 2008, 2012; Dell'Ariccia et al., 2016).

First, credit booms have been consistently linked to sharp increases in capital inflows triggered by periods of disinflation or by low interest rates in developed economies, factors that consequently raise the supply of loanable funds (Gourinchas et al.et al., 2001; Calderón and Kubota, 2012; Gourinchas and Obstfeld, 2012; Blanchard et al., 2017). These surges are usually associated with a rapid build-up of leverage or to a higher ratio of private credit to bank deposits which, in turn, may lead to financial fragility (Borio and Disyatat 2011; Gourinchas and Obstfeld, 2012). In particular, rising inflows of foreign capital may lead to excessive monetary and credit expansions (Sidaoui et al., 2011), increase the vulnerabilities associated with currency and maturity mismatches (Akyuz, 2009), and create distortions in asset prices (Agnello and Sousa, 2013; Agnello et al., 2012). Some strong evidence of the role played by capital inflows is particularly found in housing market studies: Sá et al. (2014) report that capital inflows shocks generate housing booms, while Sá and Wieladek (2015) show a positive connection between these influxes and house price growth.

Second, productivity shocks are also identified as a phenomenon that can pressure capital stock to increase at a higher rate than GDP, thus strongly raising the credit-to-GDP ratio. In addition, a better economic environment can also promote the build-up of credit (Mendoza and Terrones, 2008, 2012; Meng and Gonzales, 2017; Mimir, 2016).

Finally, researchers point out that financial reforms associated with financial liberalization, the reduction in banks' reserve requirements and increases in the provision of financial services may also contribute to more liquidity and to abnormal lending growth. ${ }^{2}$ In this context, Agnello et al. (2012) show that the removal of policies towards directed credit and

\footnotetext{
${ }^{1}$ For some recent theoretical papers on the subject, see Boissay et al. (2016) and Burnside et al. (2016).

${ }^{2}$ Mendoza and Terrones (2012) point that productivity surges, financial reforms, and massive capital inflow episodes appear before $20 \%$ to $50 \%$ of the peak of credit booms in industrial and emerging market economies.
} 
excessively high reserve requirements and improvements in the securities market reduces inequality. As a result, middle class stagnant incomes press politicians to expand credit and to ease housing affordability (Rajan, 2010).

In addition, some studies also suggest that some domestic differences may account for the uneven incidence of booms across countries: expansionary monetary and fiscal policies; less flexible exchange rate regimes; weak supervision of the banking system; and debt composition (Elekdag and Wu 2013; Arena et al., 2015; Dell'Ariccia et al., 2016; Avdjiev et al., 2018).

\section{The role of the political environment and of Central Bank independence}

In this paper, we explore the importance of the political environment and central bank independence in explaining the likelihood of credit booms. Although unexplored from the econometric point of view, the relationship between politics and credit booms or financial crises has been debated in the related literature. For example, McCarty et al. (2013) discuss how political decisions and policy subtleties in the US contributed to the housing and credit bubble that occurred in the first decade of this century; Calomiris and Haber (2014) present historical evidence and discuss the political background of banking crises; and Fernandez-Villaverde et al. (2013) debate the political dynamics of credit cycles in the Eurozone and its consequences.

There are arguments to assume that the length of credit booms might be influenced by the electoral agenda, political orientation, government support, and even political stability. Since the 1970s numerous papers have studied the connection between politics and the economy either by highlighting the relationship between economic performance and governments' electoral success or by identifying politically driven policies affecting several macroeconomic variables. ${ }^{3}$

Of particular interest are the theories of "opportunistic" political business cycles, which suggest that governments try to induce short-term economic expansions before elections with the

\footnotetext{
${ }^{3}$ For encompassing surveys, see Franzese (2002) and Paldam (2004).
} 
expectation that this may improve their chances of reelection (Nordhaus, 1975; Rogoff and Sibert, 1988; Rogoff, 1990). Conflicting with this theory, we find a different strand of literature, known as "partisan", arguing that governments are heterogeneous in the sense that they tend to exhibit different priorities when it comes to the economy. The most highlighted difference is that left-wing governments pursue low unemployment at the cost of higher inflation, while right-wing governments prioritize low inflation at the expense of higher unemployment. Tendencies to increase taxation, to reinforce the state's intervention in the economy or to increase expenditures are considered traits also more associated with left parties than with other parties (Hibbs, 1977; Alesina, 1987; Alesina and Sachs, 1988). When linking political ideology to credit expansions, we believe that one of two opposing scenarios can occur. First, since right-wing governments are traditionally more prone to reduce state intervention, foster liberalization and to exert less control over the markets, one should expect them to contribute to an increase in the likelihood of a credit boom and the inverse should happen with left-wing governments. Broz (2010) shows that the expansion period of financial cycles is normally accompanied by the election of right-wing governments. Second, there are some traits generally associated with right-wing parties like a higher propensity for inflation control, smaller deficits and a lower inclination to implement income redistribution that may legitimize the opposite effect. The fact that the redistribution of income should be greater when left-wing governments are in power (see Bradley et al., 2003 and Iversen and Soskice, 2006) means that, under the left's rule, more people are expected to access credit or get involved in the financial markets. ${ }^{4}$ This will contribute to an increase in the rate of credit expansion. The reverse should happen when right-wing parties are in office.

Another environmental aspect to consider is that higher degrees of government neutrality and also overall political stability - like the presence of majority governments and reduced government turnover (ideological changes) - normally produce a more stable economic

\footnotetext{
${ }^{4}$ In fact, Popa (2013) shows that the size of the house price bubbles across countries is mainly related to the percentage of homeowners, with more homeowners linked to larger bubbles.
} 
environment. More stability means that less uncertainty and an increase in the overall confidence is felt across most markets, creating favorable conditions for consumption and investment to thrive, thus pressuring credit to grow faster. For instance, Agnello and Sousa (2013) show that higher public deficit volatility is typically linked to more political instability and less democracy .

Regarding the linkage between lending growth and the electoral agenda, ample evidence is found relating policy uncertainty generated by elections with delayed investments, more so when the electoral race is tight (see Jens, 2017; Canes-Wrone and Park, 2014). The disruption and uncertainty caused by elections can have a negative effect on credit expansion. Alternatively, one could also argue that if opportunistic governments are successful in giving a significant boost to the economy prior to elections then these temporary positive shocks can eventually fuel credit booms. However, the theory predicts that after the elections governments are forced to contract the economy to correct the artificial unbalances generated previously, meaning that the positive pre-electoral effect may be mitigate or even canceled in the aftermath of the full political cycle.

Monetary policy is also an important theoretical factor to the understanding of why in some periods credit growth exhibits an excessive pace while in others it does not. Central Banks are the institutions that regulate the quantity of money present in the system. During a credit expansion, Central Banks typically exhibit a loose monetary policy of low interest rates that makes it easier for economic agents to obtain credit which eventually leads to more and cheaper investments, thus helping to place credit growth above normal standards. They also play an important role in the monitoring of the financial system and in preventing markets - and the overall economy - from overheating. However, political pressures can constrain the work of Central Banks, reducing the desired independence of these institutions. Indirectly, governments can influence Central Banks via three main sources. First, the board of the Central Bank is typically selected by parliament or by the government directly. Chappell et al. (1993) found that this appointment process is the primary channel through which political parties can influence 
Central Banks. Second, governments have the ability to send monetary policy signals to the Central Bank, using, for instance, media appearances to convey their preferences for a looser or tighter monetary policy (Havrilesky, 1988, 1991). Third, governments can threaten Central Bank officials, their jobs or question the very existence of the institution (Lohmann, 1998). These and other aggressive moves may be used to force the Central Bank's policy into a particular direction.

From the governments' perspective the policy of credit expansion is definitively a good thing. More investment and higher consumption makes people happier, and happier people tend to reward the incumbent electorally. Hence, it is reasonable to assume that governments are particularly fond of periods of abnormal credit expansion and they have no desire to have on their hands a credit crunch. They also know that monetary policy is an important tool to help creating, fuelling or delaying the crunch of a particular credit boom. As such, it is expected that less independent Central Banks increase the frequency and intensity of credit booms and that they are less prone and free to intervene when the economy displays strong signs of overinvestment, excessive risk and/or overinflated market bubbles.

\section{Data and methodology}

To assess the role of the economic conditionings, political environment and central bank independence on the likelihood of credit booms, we collected quarterly data for 67 countries (36 developed/industrial economies and 31 developing/emerging market economies) ${ }^{5}$ from $1975 \mathrm{q} 1$ to $2016 \mathrm{q} 4$ on real credit. These countries were selected according to the availability of economic and political data. This means that we consider only those countries for which there are: (i) data on deposit money bank claims on the private sector; (ii) reasonably long series for the main economic conditionings; (iii) and regular/frequent and competitive elections and changes in the political orientation of the government over the time period considered in this study.

\footnotetext{
5 This distinction between developed and developing/emerging countries is based on the United Nations (UN) definition (see UN, 2016 and several previous issues). The list of countries is presented in Table A1 in Annex.
} 


\subsection{Identification of credit booms}

We use quarterly data on deposit money bank claims on the private sector to identify credit booms because it is more appropriate to assess cyclical movements and volatility associated with crisis episodes. This measure of credit is taken from the line $22 \mathrm{~d}$ of the IMF's International Financial Statistics (IFS). The amount of credit is then expressed in real terms by dividing the nominal credit by the CPI index (at the end of the quarter).

The definition/identification of credit boom episodes is not an easy task. The literature offers some approaches but no clear consensus on the best methodology to identify them. There seems to be no right or wrong way to identify credit boom events; each approach comes with its advantages and drawbacks (Gourinchas, et al., 2001; Tornell and Westermann, 2002; Mendoza and Terrones, 2008, 2012; Barajas, et al., 2009; Calderón and Kubota, 2012; Dell'Ariccia et al., 2016). Most of them compare a country's real credit per capita or the credit-to-GDP ratio to their non-linear trend. However, they diverge in some features, being some of the most important features: (i) the filtering of credit and GDP series independently or directly as a ratio; (ii) and whether the trend, the thresholds or both are specific to each country.

The analysis provided in this study uses the criteria developed by Gourinchas, et al. (2001) - and later fine-tuned by Barajas et al. (2009) - to identify credit booms. Hence, a credit boom (CreditBoom) is defined as an episode where the deviation of the real bank credit to the private sector, as a percentage of real GDP, from a country-specific trend in country $i$ at period $t$ (with the trend being calculated up to that period $t$ ) exceeds a determined threshold. ${ }^{6}$ In

\footnotetext{
${ }^{6}$ The advantage of the ratio of private credit-to-GDP is that it relates private credit to the size of the economy and corrects for the pro-cyclicality in bank lending. For other procedures see, for example, Mendoza and Terrones (2008, 2012), Dell'Ariccia et al. (2016) and Avdjiev et al. (2017). While Dell'Ariccia et al. (2016) identify boom episodes by comparing the credit-to-GDP ratio in each year $t$ and country $i$ to a backward-looking, rolling, country-specific, cubic trend estimated over the period between years $t-10$ and $t$, Mendoza and Terrones $(2008,2012)$ use the
} 
particular, a credit boom takes place if the ratio of private credit to GDP meets the following condition: the deviation of this ratio from its estimated trend is greater than 1.5 times its standard deviation or the year-on-year growth rate of private credit to GDP exceeds 20 percent. $^{7}$ According to this definition, we identify 220 episodes of credit boom episodes over our entire sample: 67 countries; 1975q1-2016q4. On average, they last around 8 quarters are longer in developing countries and more than a half of those episodes took place in developing or emerging economies. ${ }^{8}$

\subsection{Macroeconomic determinants}

In the right-hand-side of the equation we start by introducing the potential economic drivers of credit booms. The variables considered are among those most commonly used in the existing literature, namely:

- Total gross capital inflows as percentage of GDP (CapInflows). This is the main proxy for capital inflows and includes information from three main components: foreign direct investment, portfolio investment and other investment liability inflows. The data for this variable (and respective components) comes from the IMF's Balance of Payments Statistics (BOP), while data for GDP is gathered from the World Bank's World Development

deviation of the real credit per capita from its long-run trend to identify those booms. More rencently, Avdjiev et al. (2018) use the methodology applied by Agnello et al. (2015) and Burnside et al. (2016) to the housing market cycle. Their method consists of the following steps: (i) smooth the series of the quarterly (real) credit to the private nonfinancial sector using a (centred) moving average; (ii) detect periods of consecutive upturns (i.e. positive growth) and downturns (i.e. negative growth) in the smoothed series, thus, dating its turning points (i.e. peaks and troughs); (iii) build on historical variation to set (average) thresholds of (cumulative) (real) growth; and (iv) if cumulative growth over a period of consecutive upturns (downturns) exceeds (falls below) a minimum (maximum) bound, then it is labelled as a boom (bust).

${ }^{7}$ The HP-filter is used to compute the trend, where the value of Lagrange Multiplier employed in the maximization problem is $\lambda=1600$ (for quarterly data). For robustness, we also consider later other more restrictive thresholds (1.75 and 2.0) and Mendoza and Terrones (2008, 2012) approach.

${ }^{8}$ For details, see Table A1 in Annex. 
Indicators (WDI). The respective components will be considered later as a sensitivity analysis. In line with the literature (Gourinchas et al., 2001; Calderón and Kubota, 2012; Gourinchas and Obstfeld, 2012; Blanchard et al., 2017; among others), we conjecture that total capital inflows are positively related to the likelihood of credit booms.

- Ratio of private credit to bank deposits (Credit/Deposits). This is a proxy for liquidity in the banking system, where deposits are measured as the sum of demand and time deposits (IFS lines 24 and 25, respectively). We anticipate that credit booms are more likely when liquidity is lower (Borio and Disyatat 2011; Gourinchas and Obstfeld, 2012; among others). Hence, we expect that credit booms will build up with credit growing faster than deposits. ${ }^{9}$

- Interest rate spread (IRspread). This is a measure for the banking margin which accounts for the relative price of credit. It is computed as the difference between the average lending rate and the deposit rate, in percentage. These data are collected from the IMF's IFS. Even though the cost of credit is neglected to be directly addressed by most of the studies (with the exception of Barajas et al., 2007), this is an important conditioning to be accounted for (see, for instance, Benbouzid et al. 2017a, 2017b). We expect that credit booms are less likely when the relative cost of credit is high.

- Growth rate of real GDP (RGDPgr). Quarterly data of real GDP (in local currency at constant prices) is obtained from Datastream and national sources to compute the yearover-year GDP growth rate. According to the literature (Mendoza and Terrones, 2008, 2012; Gourinchas and Obstfeld, 2012; Dell'Ariccia et al., 2016; Mimir, 2016; Meng and Gonzales, 2017; among others), we conjecture that a better economic environment favours the build-up of credit booms, making them more likely.

\footnotetext{
${ }^{9}$ Other measures of credit are also considered later in this study to assess their impact on the building up of a credit boom: ratio of real credit to GDP and to population.
} 
- Inflation rate (Inflation). It is measured by the (year-over-year) percentage change of the consumer price index $(\mathrm{CPI})$ and the data is from the IMF's IFS. In this case it is not easy to conjecture a sign for its impact: on one hand, price instability may generate uncertainty and less willingness for economic agents to invest; but, on the other hand, it may promote credit booms if the monetary policy is loose, i.e. if the monetary authorities do not intervene by rising the interest rate accordingly to adjust the cost of borrowing.

- Current account balance as percentage of GDP (CurrAccount). Gourinchas et al. (2001) show that credit booms are associated with a worsening of the current account, so we expect to confirm this finding. Data for this variable are obtained from the WDI.

- Trade openness (Openness). This is equal to exports plus imports over GDP (source: IMFIFS). Even though there is no clear evidence of its impact on credit booms (see, for example, Dell'Ariccia et al., 2016), we conjecture that more opened economies may need to rely more on credit to finance their external commitments at some points in time, which may generate a temporary surge in credit.

- Overvaluation of the real effective exchange rate (ApprecREER) as a proxy for asset prices. This variable is obtained using quarterly data from the IMF's IFS. An increase in the REER index means a real appreciation; An overvaluation is measured as the deviation of the REER index from its HP-filtered trend. As an increase in this variable translates into a rise in asset prices, this might lead to an increase in credit to keep up with the rise in asset prices. Hence, according to Calderon and Kubota (2012), we anticipate that a real exchange rate overvaluation will raise the likelihood of a credit boom.

- Exchange rate flexibility (ExchRateFlex). This variable is proxied by the coarse classification of the exchange rate regime developed by Reinhart and Rogoff (2004), and updated by Ilzetzky, Reinhart and Rogoff (2009) and similar sources mentioned in that paper for more recent years. The coarse index varies between 1 and 6: higher values 
indicate a more flexible exchange rate arrangement. According to Dell'Ariccia et al. (2016, p.16): "In economies with fixed exchange rate regimes, monetary policy is directed towards maintaining a fixed exchange rate and is, therefore, unable to respond effectively to the build-up of a credit boom." So, we expect that more flexible exchange rate arrangements are negatively related to the likelihood of credit booms.

\subsection{Political environment and central bank independence}

To account for the yet unexplored influence of the political environment on the likelihood of credit booms, we employ the following political variables borrowed from the political business cycles and partisan literature: ${ }^{10}$

- Year before election (YrBefElection). This dummy variable takes the value of 1 in the 4 quarters before the election, and 0 otherwise. Later, in the sensitivity analysis, it will be replaced by the election quarter dummy (ElectionQtr), election year dummy (ElectionYr) and year after the election dummy (YrAftElection). It is expected that the uncertainty in the months leading to elections might not be beneficial for credit booms; as discussed in the previous section, the opposite effect can also be admissible, although less likely to occur.

- Political orientation dummies: Right, Centre, and Left. These dummies take the value of 1 when the government if formed by a right-wing, centre, or left-wing party, respectively,

\footnotetext{
${ }^{10}$ The data for all political variables used in this study were collected from the Database of Political Institutions 2015. The DPI is in an annual database, so we had to construct a quarterly version of the data. Since we had quarterly information on the date of all elections, we use this information to change the annual nature of the data for all political variables used in this study to quarterly data at election points. For those changes found in the annual data that were not accounted by elections we opted by leaving them annually-based. As such, our quarterly variables (excluding YrBefElection, ElectionQtr and YrAftElection) are only partially quarterly variables. Nevertheless, they are clearly more accurate than their annual counterparts.
} 
and 0 otherwise. ${ }^{11}$ As discussed in the previous section, there is no clear theoretical prediction for how government ideology affects credit booms; as such; this dimension is open to the empirical debate.

- Majority government dummy (MajorityGov), which takes the value of 1 when the government formed by a governing party that has an absolute majority of seats in the legislature or parliament. Majority governments may help to promote a more stable economic environment, therefore, creating conditions for credit booms to thrive.

- Number of government changes (NGovChanges). This variable records the number of government changes (due to elections or not) over the previous five years. Overall, political stability delivered by the presence of majority governments and reduced government turnover (and, hence, ideological changes) are expected to promote credit booms.

Additionally, our baseline specification also accounts for the role of the following institutional factors:

- Central Bank independence $(C B I)$. This is the Cukierman-Webb-Neyapti weighted Central Bank independence index updated by Garriga (2016) to measure the respective degree of independence. It varies between 0 and 1: the closer it is from 1, the more independent the Central Bank is. It is expected that the more independent Central Banks are, the more prone and free to intervene they are when the economy displays strong signs of overinvestment, excessive risk and/or inflated market bubbles. Hence, credit booms might be less likely the more independent the Central bank is.

\footnotetext{
${ }^{11}$ The DPI divides parties into three groups based on an evaluation of a party's orientation with respect to economic policy. For single party majority governments, the indictor variable corresponding to its ideology takes the value one in years during which the party rules a given country. For coalition governments, the DPI classifies a coalition government as having the ideology of the largest coalition partner. The group of right-wing parties includes conservative, Christian democratic, and other right-wing parties; the group of left-wing parties includes communist, socialist, social democratic, and other left-wing parties; and the group of Centre includes parties defined as centrists or which party position can best be described as centrist.
} 
- Monetary Union $(M U)$. This is a dummy variable that takes the value of 1 when the country's monetary policy is in the hands of a regional monetary union (for example, the members of the Eurozone or Central Bank of West African States). With this variable, we intend to capture spillover and/or contagion effects over the members of a monetary union.

Other economic and political variables are also considered later in the sensitivity analysis. $^{12}$

\subsection{Empirical framework}

As the dependent variable used in this analysis is a dummy, we rely on a binary choice model to estimate the coefficients of interest. A logit model is employed to explain the probability of a credit boom occurring in country $i$ at quarter $t$, given the economic (Econ), political $(\mathrm{Pol})$ and institutional (Inst) conditionings described above. Hence:

$$
\operatorname{Prob}\left(\text { CreditBoom }_{i t}=1 \mid \text { Econ }_{i t-1}, \text { Pol }_{i t}, \text { Inst }_{i t}\right)=\Lambda\left(\boldsymbol{\alpha}^{\prime} \text { Econ }_{i t-1}+\boldsymbol{\beta}^{\prime} \text { Pol }_{i t}+\gamma^{\prime} \text { Inst }_{i t}\right),
$$

where $\boldsymbol{\alpha}, \boldsymbol{\beta}$ and $\boldsymbol{\gamma}$ are the vectors of the parameters to be estimated and $\Lambda(\cdot)$ is the logistic cumulative distribution function. As the logit model is to be estimated over a panel of 67 countries over the period 1975q1-2016q4, a panel data analysis is considered. The application of binary models to panel data analysis is straightforward (see Greene, 2012, Ch.17). The structural model for the panel data to be estimated in this study can be written as follows:

$$
\begin{aligned}
& y_{i t}^{*}=\boldsymbol{\alpha}^{\prime} \text { Econ }_{i t-1}+\boldsymbol{\beta}^{\prime} \text { Pol }_{i t}+\gamma^{\prime} \text { Inst }_{i t}+\varepsilon_{i t}, \quad i=1, \ldots, 67 ; \quad t=1975 q 1, \ldots, 2016 q 4 \\
& \text { CreditBoom }_{i t}= \begin{cases}1 & \text { if } y_{i t}^{*}>0 \\
0 & \text { otherwise }\end{cases}
\end{aligned}
$$

\footnotetext{
${ }^{12}$ See Table A2 in Annex for the descriptive statistics of all variables used in this study concerning the maximum number of countries that could be used in the estimations.
} 
where $y_{i t}^{*}$ is the usual unobserved latent variable and $\varepsilon_{i t}$ is the error term which may include country specific effects $v_{i}$ (random or fixed) and time effects $\tau_{t}$. To begin with, we account for all these effects and then select the best estimation procedure (pooled, fixed-effects or randomeffects) according to the usual panel-data tests. The respective empirical results are analysed next.

\section{Empirical analysis}

This section starts with the discussion of the main results from the estimation of the logit model. Then some sensitivity analyses and robustness checks are provided.

\subsection{Main findings}

The results from our baseline specification are presented in Table 1. First, only the main economic factors that are identified in the literature as the main conditionings of credit booms are considered. Then, the new explanatory dimensions proposed in this paper are added, hence assessing the impact of political and institutional factors in the build-up of credit booms. For each variable we report the estimated marginal effects, the respective standard-errors and degree of statistical significance (signalled with asterisks). The number of observations, countries used in each estimation, the respective number of credit boom episodes, ${ }^{13}$ log-likelihood (LogL), Schwarz Bayesian Information Criterion (SBIC) and McFadden's pseudo- $\mathrm{R}^{2}$ are reported at the bottom of the table. There we also show the results of panel data and endogeneity tests.

The panel data tests favour the FE Logit estimator relatively to both the ordinary Logit and RE Logit. This means that country effects must be accounted for. Decade-dummies have also proved to be relevant; hence, they are included in all estimations to control for time effects (one

\footnotetext{
${ }^{13}$ Table A3 in Annex reports the list of countries and events that are used in the estimations. Due to the lack of variability or lack of data for some variables/countries, a few countries were excluded from the estimations. This means that we end up with a maximum of 51 countries and 96 boom episodes in our regressions.
} 
for each decade since the 1970s: Dec70, Dec80, Dec90, Dec00, Dec10; Dec70 is the basecategory. Their estimates are not reported here to save space). ${ }^{14}$

\section{[Insert Table 1 around here]}

All economic variables are lagged one period to avoid simultaneity problems and to account for the usual delays in the reporting of economic data. Looking first at the results with only those variables (columns 1-3), we confirm the main findings in the literature. In particular, considering our preferred estimation procedure (FE Logit), we show that credit booms are more likely when: (i) capital inflows are boosted; (ii) liquidity is lower (i.e. credit is growing faster than deposits); (iii) credit is relatively cheap; (iv) the economy is growing faster; (v) inflationary pressures are not suitably accommodated by monetary authorities; the current account balance improves (which means more cash/liquidity available and less need for further credit); and when the economy is more open to trade. In sum, we conclude that credit booms depend not only on the quantity of credit (TotCapInflows and Credit/Deposits), but also its relative price (IRspread). ${ }^{15}$ At the same time, higher levels of economic growth (RealGDPgr) and trade openness (Openness) also contribute to build-up the conditions for them to become more likely. On the contrary, economies that can generate more liquidity (better CurrAccount position and higher level of deposits) are less prone to be affected by credit booms.

Most of these results remain valid when political and institutional factors are added (see columns 4-6). The exceptions are the inflation rate, which is no longer relevant, and the overvaluation of the REER, which shows the expected positive effect. Nevertheless, the main novelties of this paper come from the results for the political and institutional conditionings. Despite no evidence of an electoral cycle is found in the build-up of credit booms

\footnotetext{
${ }^{14} \mathrm{We}$ should note that as probit models do not render themselves well to the fixed effects treatment, due to the incidental parameters problem (Wooldridge 2002, Ch. 15, p. 484), a (fixed effects) logit is used instead.

${ }^{15}$ In particular, when TotCapInflows or Credit/Deposits (IRspread) increases by 1 percentage point, the likelihood of a credit boom increases (decreases), respectively, by around 1.51 or $0.77(0.24)$ percentage points, ceteris paribus.
} 
(YrBefElection), they have proven to be less likely when right-wing parties (Right) are in office: the probability of a credit boom is 6.4 percentage points lower with right-wing governments than with centre or left-wing ones. This result is at odds with the idea that right-wing governments should foster credit boom episodes because they are traditionally more liberal and tend to exert less control over the economy. Perhaps the resistance they exhibit towards the policy of income redistribution, their tendency for smaller deficits and tighter inflation control may be retracting the occurrence of credit booms. This effect is examined more closely further ahead.

The idea that political instability could reduce the likelihood of credit booms is only supported by the negative effect found for the variable NGovChanges. More frequent government turnovers are probably increasing economic uncertainty, hence reducing investment and the demand for credit. However, the extra stability that majority governments are expected to provide does not seem to be relevant. We return to this subject in the sensitivity analysis (see Table 3 ) where we introduce the International Country Risk Guide (ICRG) index of government stability.

Regarding the institutional controllers we also get some striking findings. Variations in Central Banks' independence $(C B I)$ affects credit surges and, as expected, the more independent they are, the lower the propensity for credit booms will be. Their greater independence to intervene with the adequate monetary policy measures when the economy is showing signs of overinvestment, stock and housing market bubbles, excessive risk and too much credit is detrimental to mitigate the accrual of credit booms.

Additionally, we find that when the country's monetary policy is in the hands of a regional monetary union $(M U)$, credit booms are more likely to occur. This is a surprising result as the only countries belonging to a Monetary Union in our estimations are Eurozone members. Due to missing values and lack of variability of some variables, the Central Bank of West African States end up being excluded from the estimations. Nevertheless, this result might be indicating the presence of credit spillovers or contagion effects over the members of this monetary union. 
Given countries asymmetries it may not be easy for the monetary authority to tackle potential credit booms with a policy that fits them all and without hurting some states.

Even though we use lags of the economic variables to account for simultaneity problems, the endogeneity issue is directly addressed in regressions 7 and 8 by employing two instrumental variables approaches: an IV-Probit and a two-stage FE IV-Logit. The first estimator is a standard IV-Probit where fixed-effects are not accounted for. As this estimator does not provide consistent estimates with fixed-effects - and they are present - we rely on an alternative fixed-effects IVLogit estimator, where we follow the traditional two-stage instrumental variables approach. In the first-step, as in the IV-Probit, potential endogenous economic variables like TotCapInflows, Credit/Deposits, IRspread and RealGDPgr are assumed to be endogenous and they are instrumented using their respective four lags and a dummy that takes the value of one when a country is hit by a banking crisis (BankCrisis). It is expected that such crises may affect the inflows of capital, the credit-to-deposits ratio, relative price of credit and growth. All instruments have proven not to be weak in the first-step OLS estimations (with both estimators). In the second-step, the fitted values for those four potentially endogenous regressors are used in the estimation of a fixed-effects logit (in the same fashion as in the IV-Probit). The previous results and conclusions remain unchanged and we also conclude that endogeneity is not an issue in our analysis as the Wald exogeneity test in the IV-Probit and the Durbin-Wu-Hausman test in the FE IV-Logit do not reject the exogeneity hypothesis. ${ }^{16}$

Overall, we conclude that not only the economic but also the political environment, the degree of Central Bank independence and monetary unions matter for the understanding of the likelihood of credit booms.

\subsection{Sensitivity analysis}

\footnotetext{
16 We also considered other variables as potentially endogenous and other instruments but, in general, the conclusions were similar. The results of those experiments are not reported here, but they are available upon request.
} 
To check for the sensitivity of these results to changes in the controllers, we provide next an analysis where different proxies are used to account for the economic, political and central bank independence measures (Tables 2-4).

Table 2 presents the results of some sensitivity tests to the economic variables. First, we start by replacing TotCapInflows by its components: foreign direct investment inflows (CapInflowsFDI), portfolio investment inflows (CapInflowsPI), and other investment inflows (CapInflowsOI), respectively. The results show that the total positive effect of capital inflows on the likelihood of credit booms is mainly driven by portfolio and other investment inflows. This confirms the growingly complex flow and stock dynamics in financial markets. In particular, the dynamics of FDI debt flows - which include (increasing) intra-group flows, such as offshore debt issuance - are becoming closer to the dynamics of (volatile and more vulnerable) portfolio debt flows than to those of (resilient and more stable) FDI equity flows. The complexity of large multinational companies is also contributing to the rise in other non-bank investments (BIS, 2017). For instance, the majority of FDI claims and liabilities in large financial centres refers to Special Purpose Entities - i.e. entities that raise capital or hold assets/liabilities that typically perform no production - whose importance is also growing (Lane and Milesi-Ferretti, 2017). ${ }^{17}$

\section{[Insert Table 2 around here]}

Next, we used the credit to GDP ratio (Credit/GDP) and the real credit per capita (RealCredit/Pop) instead of Credit/Deposits as alternative proxies for liquidity. Despite the marginal effect on the first is not significant, RealCredit/Pop confirms the quantity of credit as an important driver of credit booms. The results in column 6 also corroborate the conclusion that not only the quantity, but also the price matters. Replacing IRspread by its components, we show that higher lending rates (LendRate) deter the economy from credit booms, while higher deposit rates (DepositsRate) seem to have an opposite effect. In the end, it is their spread (i.e. relative price or

\footnotetext{
${ }^{17} \mathrm{We}$ are grateful to one of the referees for bringing this to our attention.
} 
banking margin) that defines the direction of the overall effect, which has proved to be significantly negative, as expected. This is an important finding regarding the price-effect to which the literature on credit booms has not given a proper attention so far.

The sensitivity of the exchange rate flexibility indicator was also checked by using the fine measure (ExchRateFlexF) proposed by Reinhart and Rogoff (2004), but no relevant change is found relatively to the coarse measure. Despite all these experiments, the results for the other conditionings remain qualitatively and quantitatively unchanged.

Recently, Avdjiev et al. (2018) highlight the role played by external debt composition in shaping the dynamics of credit cycles. As our study is concerned with the political environment, public debt and/or government deficit may also matter. Although this paper uses deposit money bank claims on the private sector to identify credit booms, an increase in public debt or government deficit may also affect the likelihood of credit booms. Therefore, as an additional experiment with the economic controllers, we test their impact on the likelihood of credit booms by adding the variables gross general government public debt (Debt) and government budget surplus $(G o v B S)$, both as a percentage of GDP, to the baseline specification. The results provide some evidence (even though weak) that credit booms are more likely when public debt and deficit increase. ${ }^{18}$ As right-wing governments have a higher propensity for lower deficits and debt, this may help to justify why credit booms are less likely when they are in office.

Table 3 reports the results for the sensitivity analysis regarding the political variables. The dummy YrBefElection is successively replaced by ElectionQtr, Election Yr and YrAftElection. These alternative dummies for the political cycle are equal to 1 , respectively, in the election quarter, election year and in the year after the election (and 0 otherwise). None of the respective marginal effects is statistically significant, which confirms our initial findings that no electoral cycle is present in the credit booms' dynamics.

\footnotetext{
${ }^{18}$ However, these results are not robust to the changes in the other regressors and, therefore, they should be analysed with a grain of salt.
} 


\section{[Insert Table 3 around here]}

Regarding partisan effects, we confirm that credit booms are indeed more likely with both centre and left-wing governments, but they seem to thrive more when centre parties (Centre) are in office as the magnitude of its marginal effect is substantially higher than the one associated to Left (see column 4). Even though the propensity of credit booms is not affected by the presence of majority governments, we find that when they are split into single party majority governments (SPMajGov) and coalition majority governments (CoalMajGov), this second type has a marginal positive influence on the propensity for credit booms to arise. As alternative proxies for political stability we tried, in regressions 6 and 7, the number of quarters a party is in office (PartyTenure) and a risk rating indicator for government's ability to carry out its declared program(s) and to stay in office (GovStability). ${ }^{19}$ The higher this indicator is, the lower the government stability risk. With this indicator we corroborate the idea that government stability is favourable for credit booms to flourish. Despite these experiments, results for the other variables remain unaffected.

The last set of sensitivity tests reported in Table 4 has to do with the role of the Central Bank and monetary unions. Different measures for the degree of Central Bank independence provide essentially the same results. In column 1 the unweighted Central Bank independence index computed by Garriga (2016), CBI_unwgted, is used instead CBI; in regressions 2 and 3, $C B I$ is replaced by and two alternative indices: $C B I \_H \& B \_$wgted and $C B I \_H \& B \_u n w g t e d$. These are, respectively, the weighted and unweighted Central Bank indices developed by Hicks and Bodea (see http://www.princeton.edu/ rhicks/data.html). Despite the number of observations and countries is lower, we are still finding that more independence is hostile to credit booms.

\section{[Insert Table 4 around here]}

One of the instruments that Central Banks can rely on to stabilise any inflationary pressures, market bubbles or misalignments from the economic fundamentals is the Central Bank

\footnotetext{
${ }^{19}$ Data for this indicator comes from the International Country Risk Guide (ICRG).
} 
monetary policy-related interest rate (CBankRate). However, it does not seem to be as effective as the actual market lending rate or interest rate spread charged by commercial banks. Even though the Central Bank is not successful in controlling the occurrence of credit booms by managing the price of money, it is more prolific in mitigating them when acts over the supply of money: a decrease in the growth rate of M2 (M2gr) contributes to a decrease in the likelihood of a credit boom. Even though the number of observations is slashed to half, the findings for the other variables remain unchanged. Additionally, we also try to uncover interaction effects between $\mathrm{CBI}$ and political orientation $\left(C B I^{*}\right.$ Right, $C B I^{*}$ Centre, $C B I^{*}$ Left $)$ and monetary union $\left(C B I^{*} M U\right)$ but no statistically significant effects were found for the coefficients on those interactions (see columns 6-8). However, regarding the political orientation, the ideological effect becomes weaker when interaction effects are considered, while the coefficient on $C B I$ remains highly significant. This might indicate that more independent central banks can overrule the propensity for left-wing governments to promote credit booms and help right-wing governments to relax their concerns on this matter.

Additional experiments were made considering other interactions between the political and institutional variables and using different definitions of credit booms and different thresholds but the main results and conclusions of this study remained unchanged. ${ }^{20}$

\subsection{Robustness checks}

As a robustness check, we split our sample in two groups: developed and developing/emerging countries. ${ }^{21}$ The idea is to assess whether these heterogeneous groups are differently affected by the economic, political and institutional determinants or not.

\footnotetext{
${ }^{20}$ We tested for Gourinchas et al.et al. (2001) and Mendoza and Terrones (2008) criteria using three different thresholds for their computation: 1.5, 1.75 and 2.0. All these results are available upon request.

${ }^{21}$ This distinction is based on the United Nations definition (UN, 2016 and several previous issues). For the list of countries in each group, see Table A1 in Annex.
} 


\section{[Insert Table 5 around here]}

We begin this analysis by adding to our baseline specification a dummy variable that takes the value of one for developed countries and zero otherwise (Developed). The results presented in Table 5 (column 1) show that, on average, credit booms are (slightly) more likely in developed countries. This result is in line with the work by Martinez (2015) who argues that advanced economies are more prone to credit booms and which might be due to the moral hazard problem generated by asymmetric information in financial transactions.

In a second stage, we separate the analysis between the two groups (columns 2 and 3). We observe that, in both groups of countries credit booms are driven by a higher level of economic growth, worse current account stance, trade openness, and less independent Central Bank. Interestingly, no evidence of a political cycle is found in both cases. However, there are some noteworthy differences. Credit booms in developed countries are more likely when: capital inflows increase, the REER is overvalued, ${ }^{22}$ and with minority governments. This is not the case for developing countries. Instead these are more prone to face credit booms when the quantity of credit to deposits is higher and the interest rate spread is lower and with majority governments. This later effect may relate to the fact that developing countries exhibit less established democracies, therefore majority governments might be more critical for government stability.

One noteworthy result found is that the enduring negative impact of right-wing governments on the likelihood of credit booms reported in the previous estimations seems to be restricted to developing countries and it is a characteristic of the 1990s and especially of the first decade of this century (see column 7). Overall, some traits generally associated with right-wing parties like a higher propensity for inflation control, smaller deficits and a lower inclination to implement income redistribution may help understand this negative effect. Additionally,

\footnotetext{
${ }^{22}$ In this context, some of recent studies have highlighted the particular role that the US dollar plays as the premier global funding currency in the international financial system (Rey, 2015; Bruno and Shin, 2015a, 2015b).
} 
developing/emerging countries have more fragile economies, a characteristic that may reinforce the need for such policies. Nevertheless, to further understand this effect we check for differences between right wing governments and other incumbents in developing countries regarding the economic determinants of credit booms. All economic variables were tested, but only the results that were found to be statistically significant are reported (see columns 4-6). The negative effect of the relative price of credit reported in column 3 only happens during the right's ruling (see column 4). This can also be linked to their greater willingness to control inflation. Additionally, when centre or left-wing parties are in office in developing countries, inflation has a significant positive impact on the likelihood of a credit boom; however, that impact is significantly reduced with right-wing governments (see column 5). Similarly, the negative effect of a better current account stance on the likelihood of credit booms is counteracted by governments ideologically leant to the right. As for the other economic variables no significant differences were found.

As those developing/emerging countries that belong to the Central Bank of West African States monetary union are excluded from our estimations - for the reasons given above - the dummy $M U$ is omitted in the regressions with developing countries only. To assess whether the results might be influenced by the Eurozone monetary union, Table 6 provides separate regressions for the sub-samples of Eurozone monetary union countries and all the others that do not belong to a monetary union. The results do not show significant differences between the sample of non-MU countries and the estimations reported above for the whole sample. The only exception is that the impact of total capital inflows becomes irrelevant in this sub-sample. However, it remains highly significant for the Eurozone MU countries. Inflation also plays a significant role in this group of countries. Hence, promoting price stability is an important task for the European Central Bank as it also has the benefit of preventing credit booms. Regarding the political factors, while the political orientation and the number of government changes are 
irrelevant, majority governments are more prone to avoid credit booms in this MU. Central Bank independence has also proven to be detrimental on that matter.

\section{[Insert Table 6 around here]}

As a final exercise, we test the robustness of our findings restricting the sample to the period before the recent Global Financial Crisis (GFC), i.e. to the period before 2007q4. The results reported in Table 6, columns 3-5, show no significant differences for both the entire sample of countries and the sub-sample of developed countries, even though they are weaker for the sub-sample of developing countries. As the estimator does not converge when restricting the analysis to the period after the crisis, a dummy variable $(G F C)$ that takes the value of one in the period after the beginning of GFC (i.e. 2007q4-2016q4), and 0 otherwise, was added the baseline specification. The results presented in column 6 are similar to the ones reported before and show no significant difference for the period after the recent financial crisis.

\section{Conclusion}

Previous studies on credit booms have focused on their economic determinants. This paper provides valuable new insights into the dynamics of credit cycles by exploring the role of the political and institutional environment.

Estimating a fixed effects logit model over a panel of developed and developing countries for the period 1975q1-2016q4, we confirm many of the important economic drivers identified in previous studies. In particular, we show that credit booms depend not only on the quantity of credit (capital inflows and the ratio of credit to deposits), but are also influence by its relative price. At the same time, economic growth and economic openness also build-up the conditions for the appearance of lending booms. In contrast, economies that can generate more liquidity are less likely to be affected by credit booms. 
As to other aspects of lending booms, we find that they appear to be immune to the electoral cycle, meaning that the uncertainty and/or political opportunism usually associated with electoral periods seem to be irrelevant to their dynamics. However, our evidence suggests that a stable political environment improves the likelihood of having a credit boom, although the extra stability majoritarian governments are expected to provide does not seem to be relevant. Additionally, boom episodes have proven to be substantially less likely when right-wing parties are in office. Some characteristics generally associated with right-wing parties like a higher propensity for inflation control, smaller deficits and a lower inclination to implement income redistribution may be fuelling this outcome. Upon further examination, we find that this effect was restricted to developing countries and, by the most part, specific to first decade of this century. A closer inspection on how the economy impacts credit episodes in these countries under the right's ruling revealed some additional insights. Overall, the relative price of credit, inflation and the current account balance all exhibited quite different relationships with credit booms when right-wing parties were in office.

Our analysis also shows that the more independent a Central Bank is, the lower the propensity for credit booms will be. More independence increases the capacity to efficiently intervene with the adequate monetary policy measures when the economy is showing signs of overinvestment, stock and housing market bubbles, excessive risk taking and too much credit. Hence, Central Bank independence is detrimental to mitigate the accrual of credit booms. Finally, our results suggest that when a country's monetary policy is in the hands of a regional monetary union credit booms are more likely to occur. 


\section{References}

Agnello, L., Castro, V., and Sousa, R., 2012. How does fiscal policy react to wealth composition and asset prices? Journal of Macroeconomics, 34(3), 874-890.

Agnello, L., Mallick, S.K., and Sousa. R., 2012. Financial reforms and income inequality. Economics Letters, 116(3), 583-587.

Agnello, L. and Sousa, R., 2013. Fiscal policy and asset prices. Bulletin of Economic Research. 65, 154-177.

Agnello, L., Castro, V., and Sousa, R., 2015. Booms, busts and normal times in the housing market. Journal of Business \& Economic Statistics, 33(1), 25-45.

Akyuz, Y., 2009. The Management of Capital Flows and Financial Vulnerability in Asia. Initiative for Policy Dialogue Working Paper Series.

Alesina, A., 1987. Macroeconomic Policy in a Two-Party System as a Repeated Game. Quarterly Journal of Economics, 1023, 651-78.

Alesina, A. and Sachs, J., 1988. Political Parties and Business Cycle in the United States, 1948-84. Journal of Money, Credit, and Banking, 201, 63-82.

Alesina, A., Cohen, G., and Roubini, N., 1997. Political Cycles and the Macroeconomy. Cambridge, Mass. and London, The MIT Press.

Arena, M., Bouza, S., Dabla-Norris, M. E., Gerling, M. K., and Njie, L., 2015. Credit Booms and Macroeconomic Dynamics: Stylized Facts and Lessons for Low-Income Countries. IMF Working Paper 15/11. International Monetary Fund.

Avdjiev, S., Binder, S., and Sousa, R., 2018. External debt composition and domestic credit cycles. European Stability Mechanism, Working-paper series, 28, 2018.

Barajas, A., Dell'Ariccia, G., and Levchenko, A., 2009. Credit Booms: The Good, the Bad, and the Ugly. Unpublished manuscript, International Monetary Fund (Washington, DC).

Benbouzid, N., Mallick, S.K., and Sousa, R., 2017a. A forensic perspective of the determinants of banks' CDS spreads. Journal of Financial Stability, 33, 60-70.

Benbouzid, N., Mallick, S.K., and Sousa, R., 2017b. Do country-level financial structures explain bank-level CDS spreads? Journal of International Financial Markets, Institutions and Money, $48,135-145$.

BIS, 2017. 87th Annual Report, Bank for International Settlements: Basel, Switzerland. Available at: www.bis.org/publ/arpdf/ar2017e.htm. 
Blanchard, O., Ostry, J., Ghosh, A., Chamon, M., 2017. Are capital inflows expansionary or contractionary? Theory, policy implications, and some evidence. IMF Economic Review, 65, $563-85$.

Boissay, F., Collard, F., and Smets, F. 2016. Booms and Banking Crises. Journal of Political Economy, 124(2), 489-538.

Borio, C. and Disyatat, P., 2011. Global imbalances and the financial crisis: Link or no link? BIS Working Papers No. 346.

Bradley D., Huber, E., Moller, S., Nielsen, F., and Stephens, J., 2003. Distribution and Redistribution in Post-industrial Democracies. World Politics, 55(2) 193-228.

Broz, J. L., 2010. Partisan financial cycles. Politics in the New Hard Times: The Great Recession in Comparative Perspective. Ithaca, Cornell University Press.

Bruno, V., and Shin, H.S., 2015a. Capital flows and the risk-taking channel of monetary policy. Journal of Monetary Economics, 71(C), 119-132.

Bruno, V., and Shin, H.S., 2015b. Global dollar credit and carry trades: a firm-level analysis. Review of Financial Studies, 30(3), 703-749.

Burnside, C., Eichenbaum, M. and Rebelo, S. 2016. Understanding Booms and Busts in Housing Markets. Journal of Political Economy, 124(4), 1088-1147.

Calderón, C. and Kubota, M., 2012. Gross inflows gone wild: gross capital inflows, credit booms and crises. World Bank Policy Research Working Paper No. 6270.

Calomiris, C. and Haber, S. 2014. Fragile by Design: The Political Origins of Banking Crises and Scarce Credit. Princeton University Press.

Canes-Wrone, B., and Park, J., 2014. Elections, Uncertainty and Irreversible Investment. British Journal of Political Science, 44(1), 83-106.

Chappell, H.W., Havrilesky, T.M., and McGregor, R.R., 1993. Partisan monetary policies: presidential influence through the power of appointment. Q. J. Econ. 108 (1), 185-218.

Dell'Ariccia, G., Igan, D., Laeven, L., and Tong, H., 2016. Credit booms and macrofinancial stability. Economic Policy, 31(86), 299-355.

Elekdag, S., and Wu, Y., 2013. Rapid Credit Growth in Emerging Markets: Boon or Boom-Bust? Emerging Markets Finance and Trade, 49(5), 45-62.

Fernandez-Villaverde, J., Garicano, L. and Santos, T. 2013. Political Credit Cycles: The Case of the Eurozone. Journal of Economic Perspectives, 27(3), 145-66.

Franzese, R., 2002. Electoral and Partisan cycles in economic policies and outcomes. Annual Review of Political Science, 5, 369-421. 
Garriga, A., 2016. Central Bank Independence in the World: A New Dataset. International Interactions, 42(5), 849-868.

Gourinchas, P-O, Valdes, R., and Landerretche, O., 2001. Lending Booms: Latin America and the World. Economia, 1(2), 47-99.

Gourinchas, P.-O. and Obstfeld, M., 2012. Stories of the twentieth century for the twenty-first. American Economic Journal: Macroeconomics, 4(1), 226-65.

Greene, W. (2012), Econometric Analysis, 7th Ed., Prentice-Hall, Upper Saddle River.

Havrilesky, T.M.,1988. Monetary policy signalling from the administration to the federal reserve. Journal of Money, Credit and Banking, 20, 82-101.

Havrilesky, T.M., 1991. The frequency of monetary policy signalling from the administration to the federal reserve. Journal of Money, Credit and Banking, 23, 423-428.

Hibbs, D.A. Jr. 1977. Political Parties and Macroeconomic Policy. American Political Science Review, 71, 1467-87.

Ilzetzky, E., Reinhart, C., and Rogoff, K., 2009. Exchange Rate Arrangements Entering the 21st Century: Which Anchor will Hold? Cambridge, MA, Harvard University, manuscript.

Iversen, T. and Soskice, D. 2006. Electoral Institutions and the Politics of Coalitions: Why Some Democracies Redistribute More than Others. American Political Science Review, 100, 165-81.

Jens, C. E., 2017. Political uncertainty and investment: Causal evidence from U.S. gubernatorial elections. Journal of Financial Economics, 124(3), 563-579.

Jordà, O., Schularick, M., and Taylor, A., 2011. Financial Crises, Credit Booms, and External Imbalances: 140 Years of Lessons. IMF Economic Review, 59(2), 340-78.

Lane, P.R. and G.M. Milesi-Ferretti, 2017. International financial integration in the aftermath of the Global Financial Crisis. IMF Working Paper no. 115, May.

Lohmann, S., 1998. Federalism and central bank independence: the politics of German monetary policy, 1957-9. World Politics 50, 401-446.

McCarty, N., Poole, K., and Rosenthal, H., 2013. Political Bubbles: Financial Crises and the Failure of American Democracy. Princeton University Press.

Martinez, R., 2015. International Banking Flows and Credit Booms: Do Booms Go with the Flow? Mimeo. Department of Economics, George Washington University.

Mendoza, E. and Terrones, M., 2008. An Anatomy of Credit Booms: Evidence from Macro Aggregates and Micro Data. NBER Working Paper No. 14049.

Mendoza, E. and Terrones, M., 2012. An Anatomy of Credit Booms and their Demise. NBER Working Paper No. 18379. 
Meng, C. and Gonzalez, R. L., 2017. Credit Booms in Developing Countries: Are They Different from Those in Advanced and Emerging Market Countries? Open Economies Review, 28(3), $547-579$.

Mimir, Y., 2016. Financial Intermediaries, Credit Shocks and Business Cycles. Oxford Bulletin of Economics and Statistics, 78(1), 42-74.

Nordhaus, W., 1975. The Political Business Cycle. Review of Economic Studies, XLII, 169-90.

Paldam, M., 2004. Are Vote and Popularity Functions Economically Correct? in C.K. Rowley \& F. Schneider (Eds.), Encyclopedia of Public Choice (pp. 49-59). Netherlands: Kluwer Academic.

Popa, M., 2013. The Political Causes of Real Estate Bubbles. Unpublished manuscript.

Rajan, R.G., 2010. Fault lines: How hidden fractures still threaten the world economy. Princeton University Press.

Reinhart, C., Rogoff, K., 2004. The modern history of exchange rate arrangements: a reinterpretation. The Quarterly Journal of Economics, 119(1), 1-48.

Rogoff, K., 1990. Equilibrium Political Budget Cycles. American Economic Review. 801, 21-36.

Rogoff, K. and Sibert, A., 1988. Elections and Macroeconomic Policy Cycles. Review of Economic Studies. LV1, 1-16.

Sá, F., Towbin, P., and Wieladek, T., 2014. Capital flows, financial structure and housing booms. Journal of the European Economic Association, 12(2), 522-546.

Sá, F., and Wieladek, T., 2015. Capital inflows and the US housing boom. Journal of Money, Credit and Banking, 47(S1), 221-256.

Sichel, D., 1991. Business cycle duration dependence: A parametric approach. Review of Economics and Statistics, 73, 254-260.

Sidaoui, J., Ramos-Francia, M., and Cuadra, G., 2011. Global liquidity, capital flows and challenges for policymakers: the Mexican experience. In: Capital flows, commodity price movements and foreign exchange intervention. Bank for International Settlements, BIS Papers No. 57, December.

Tornell, A. and Westermann, F., 2002. Boom-Bust Cycles in Middle Income Countries: Facts and Explanation. IMF Staff Papers, Vol. 49, Special Issue.

UN, 2016 (and several previous issues). World Economic Situation and Prospects 2016. United Nations.

Wooldridge, J., 2002. Econometric analysis of cross section and panel data. Cambridge: MIT Press. 
Table 1. Likelihood of Credit Booms: Economic, Political and Institutional determinants

\begin{tabular}{|c|c|c|c|c|c|c|c|c|}
\hline MgEffects & $\begin{array}{l}\text { Logit } \\
\text { (1) }\end{array}$ & $\begin{array}{c}\text { FE Logit } \\
\text { (2) }\end{array}$ & $\begin{array}{c}\text { RE Logit } \\
\text { (3) }\end{array}$ & $\begin{array}{l}\text { Logit } \\
\text { (4) }\end{array}$ & $\begin{array}{c}\text { FE Logit } \\
\text { (5) }\end{array}$ & $\begin{array}{c}\text { RE Logit } \\
\text { (6) }\end{array}$ & $\begin{array}{c}\text { IV-Probit } \\
(7)\end{array}$ & $\begin{array}{c}\text { FE IV-Logit } \\
(8) \\
\end{array}$ \\
\hline TotCapInflows & $\begin{array}{c}0.0146^{* *} \\
(0.0061)\end{array}$ & $\begin{array}{c}0.0151 * * \\
(0.0072)\end{array}$ & $\begin{array}{l}0.0157 * \\
(0.0083)\end{array}$ & $\begin{array}{l}0.0116^{*} \\
(0.0059)\end{array}$ & $\begin{array}{c}0.0219 * * \\
(0.0110)\end{array}$ & $\begin{array}{l}0.0134 * \\
(0.0080)\end{array}$ & $\begin{array}{c}0.0190 * * \\
(0.0081)\end{array}$ & $\begin{array}{l}0.0285^{*} \\
(0.0157)\end{array}$ \\
\hline Credit/Deposits & $\begin{array}{c}0.0018 * * \\
(0.0008)\end{array}$ & $\begin{array}{c}0.0077 * * * \\
(0.0014)\end{array}$ & $\begin{array}{c}0.0086^{* * *} \\
(0.0015)\end{array}$ & $\begin{array}{c}0.0034^{* * *} \\
(0.0009)\end{array}$ & $\begin{array}{c}0.0141 * * * \\
(0.0029)\end{array}$ & $\begin{array}{c}0.0087 * * * \\
(0.0018)\end{array}$ & $\begin{array}{c}0.0037 * * * \\
(0.0009)\end{array}$ & $\begin{array}{c}0.0153 * * * \\
(0.0030)\end{array}$ \\
\hline IRspread & $\begin{array}{c}-0.0017 * * \\
(0.0007)\end{array}$ & $\begin{array}{c}-0.0024 * * \\
(0.0011)\end{array}$ & $\begin{array}{c}-0.0025^{* *} \\
(0.0012)\end{array}$ & $\begin{array}{l}0.0030^{*} \\
(0.0018)\end{array}$ & $\begin{array}{c}-0.0043 * * \\
(0.0021)\end{array}$ & $\begin{array}{c}-0.0029^{*} \\
(0.0015)\end{array}$ & $\begin{array}{c}-0.0107 * * * \\
(0.0010)\end{array}$ & $\begin{array}{c}-0.0057 * * \\
(0.0028)\end{array}$ \\
\hline RealGDPgr & $\begin{array}{c}0.0198 * * * \\
(0.0023)\end{array}$ & $\begin{array}{c}0.0154 * * * \\
(0.0026)\end{array}$ & $\begin{array}{c}0.0213 * * * \\
(0.0028)\end{array}$ & $\begin{array}{c}0.0130 * * * \\
(0.0028)\end{array}$ & $\begin{array}{c}0.0154 * * * \\
(0.0038)\end{array}$ & $\begin{array}{c}0.0136 * * * \\
(0.0033)\end{array}$ & $\begin{array}{c}0.0108 * * * \\
(0.0029)\end{array}$ & $\begin{array}{c}0.0157 * * * \\
(0.0041)\end{array}$ \\
\hline Inflation & $\begin{array}{c}0.0039 * * * \\
(0.0009)\end{array}$ & $\begin{array}{c}0.0017^{* *} * \\
(0.0008)\end{array}$ & $\begin{array}{c}0.0023 * * \\
(0.0010)\end{array}$ & $\begin{array}{c}0.0014 \\
(0.0010)\end{array}$ & $\begin{array}{c}0.0004 \\
(0.0016)\end{array}$ & $\begin{array}{c}0.0006 \\
(0.0013)\end{array}$ & $\begin{array}{c}0.0013 \\
(0.0011)\end{array}$ & $\begin{array}{c}0.0002 \\
(0.0017)\end{array}$ \\
\hline CurrAccount & $\begin{array}{c}-0.0150 \text { *** } \\
(0.0012)\end{array}$ & $\begin{array}{c}-0.0192 * * * \\
(0.0032)\end{array}$ & $\begin{array}{c}-0.0250 * * * \\
(0.0023)\end{array}$ & $\begin{array}{c}-0.0194 * * * \\
(0.0015)\end{array}$ & $\begin{array}{c}-0.0339 * * * \\
(0.0048)\end{array}$ & $\begin{array}{c}-0.0280 * * * \\
(0.0030)\end{array}$ & $\begin{array}{c}-0.0190 * * * \\
(0.0015)\end{array}$ & $\begin{array}{c}-0.0348 * * * \\
(0.0049)\end{array}$ \\
\hline Openness & $\begin{array}{c}0.0656^{* * *} \\
(0.0182)\end{array}$ & $\begin{array}{c}0.2078^{* * * *} \\
(0.0253)\end{array}$ & $\begin{array}{c}0.1891 * * * \\
(0.0350)\end{array}$ & $\begin{array}{c}0.0901 * * * \\
(0.0192)\end{array}$ & $\begin{array}{c}0.3322 * * * \\
(0.0509)\end{array}$ & $\begin{array}{c}0.1767 * * * \\
(0.0404)\end{array}$ & $\begin{array}{c}0.1122 * * * \\
(0.0212)\end{array}$ & $\begin{array}{c}0.3407 * * * \\
(0.0518)\end{array}$ \\
\hline ApprecREER & $\begin{array}{c}0.0283 \\
(0.1117)\end{array}$ & $\begin{array}{l}-0.0065 \\
(0.0723)\end{array}$ & $\begin{array}{l}-0.0319 \\
(0.1029)\end{array}$ & $\begin{array}{l}0.2570^{*} \\
(0.1322)\end{array}$ & $\begin{array}{c}0.3109 * * \\
(0.1455)\end{array}$ & $\begin{array}{c}0.2606^{* *} \\
(0.1284)\end{array}$ & $\begin{array}{l}0.2496^{*} \\
(0.1341)\end{array}$ & $\begin{array}{l}0.2917^{*} \\
(0.1496)\end{array}$ \\
\hline ExchRateFlex & $\begin{array}{c}0.0003 \\
(0.0064)\end{array}$ & $\begin{array}{c}-0.0031 \\
(0.0071)\end{array}$ & $\begin{array}{c}-0.0002 \\
(0.0091)\end{array}$ & $\begin{array}{c}0.0126 \\
(0.0081)\end{array}$ & $\begin{array}{c}-0.0088 \\
(0.0150)\end{array}$ & $\begin{array}{c}0.0014 \\
(0.0119)\end{array}$ & $\begin{array}{c}0.0173 \\
(0.0182)\end{array}$ & $\begin{array}{c}-0.0088 \\
(0.0158)\end{array}$ \\
\hline YrBefElection & & & & $\begin{array}{l}-0.0047 \\
(0.0158)\end{array}$ & $\begin{array}{l}-0.0163 \\
(0.0175)\end{array}$ & $\begin{array}{l}-0.0139 \\
(0.0151)\end{array}$ & $\begin{array}{l}-0.0022 \\
(0.0161)\end{array}$ & $\begin{array}{l}-0.0101 \\
(0.0180)\end{array}$ \\
\hline RightGov & & & & $\begin{array}{c}-0.0597 * * * \\
(0.0142)\end{array}$ & $\begin{array}{c}-0.0638 * * * \\
(0.0201)\end{array}$ & $\begin{array}{c}-0.0583^{* * *} * \\
(0.0165)\end{array}$ & $\begin{array}{c}-0.0593 * * * \\
(0.0145)\end{array}$ & $\begin{array}{c}-0.0651 * * * \\
(0.0208)\end{array}$ \\
\hline MajorityGov & & & & $\begin{array}{c}0.0048 \\
(0.0154)\end{array}$ & $\begin{array}{c}0.0142 \\
(0.0194)\end{array}$ & $\begin{array}{c}0.0042 \\
(0.0171)\end{array}$ & $\begin{array}{c}0.0179 \\
(0.0159)\end{array}$ & $\begin{array}{c}0.0104 \\
(0.0205)\end{array}$ \\
\hline NGovChanges & & & & $\begin{array}{c}-0.0159 \\
(0.0101)\end{array}$ & $\begin{array}{c}-0.0281^{* *} \\
(0.0139)\end{array}$ & $\begin{array}{c}-0.0206^{*} \\
(0.0111)\end{array}$ & $\begin{array}{c}-0.0100 \\
(0.0104)\end{array}$ & $\begin{array}{l}-0.0229 * \\
(0.0134)\end{array}$ \\
\hline$C B I$ & & & & $\begin{array}{c}-0.0651^{*} \\
(0.0391)\end{array}$ & $\begin{array}{c}-0.1900 * * \\
(0.0884)\end{array}$ & $\begin{array}{l}-0.1005^{*} \\
(0.0605)\end{array}$ & $\begin{array}{c}-0.2460 \text { *** } \\
(0.0900)\end{array}$ & $\begin{array}{c}-0.2328 * * \\
(0.0936)\end{array}$ \\
\hline$M U$ & & & & $\begin{array}{c}0.0619 * * \\
(0.0247)\end{array}$ & $\begin{array}{c}0.1946^{* * *} \\
(0.0556)\end{array}$ & $\begin{array}{c}0.1442 * * * \\
(0.0396)\end{array}$ & $\begin{array}{c}0.0788 * * * \\
(0.0259)\end{array}$ & $\begin{array}{c}0.2062 * * * \\
(0.0572)\end{array}$ \\
\hline \#Observations & 3935 & 3935 & 3935 & 3157 & 3157 & 3157 & 3033 & 2976 \\
\hline \#Countries & 51 & 51 & 51 & 47 & 47 & 47 & 47 & 45 \\
\hline \#Episodes & 96 & 96 & 96 & 88 & 88 & 88 & 88 & 85 \\
\hline $\log L$ & -1893.6 & -1520.6 & -1730.3 & -1446.5 & -1155.0 & -1342.1 & -16322.0 & -1103.7 \\
\hline SBIC & 3903.1 & 3148.8 & 3584.8 & 3054.2 & 2463.1 & 2853.4 & 33974.9 & 2359.3 \\
\hline McFadden- $\mathrm{R}^{2}$ & 0.126 & 0.156 & 0.132 & 0.127 & 0.163 & 0.131 & & 0.161 \\
\hline FE-test & & $\begin{array}{c}169.2 \\
{[0.000]}\end{array}$ & & & $\begin{array}{c}134.9 \\
{[0.000]}\end{array}$ & & & \\
\hline RE-test & & & $\begin{array}{c}326.6 \\
{[0.000]}\end{array}$ & & & $\begin{array}{c}57.1 \\
{[0.000]}\end{array}$ & & \\
\hline REvsFE-test & & & $\begin{array}{c}153.4 \\
{[0.000]}\end{array}$ & & & $\begin{array}{c}208.8 \\
{[0.000]}\end{array}$ & & \\
\hline Endog.-test & & & & & & & $\begin{array}{c}8.58 \\
{[0.072]}\end{array}$ & $\begin{array}{c}3.85 \\
{[0.427]}\end{array}$ \\
\hline
\end{tabular}

Notes: See Tables A1 and A2 in Annex. Logit estimations considering the Gourinchas et al. (2001) criteria with threshold equal to 1.5. Standard errors are reported in parentheses for each marginal effect; $* * *, * *, *$ - statistically significant at $1 \%, 5 \%$ and $10 \%$ level, respectively. \#Episodes indicates the number of episodes of booms. The Schwartz Bayesian Information Criterion (SBIC) is computed as follows: SBIC $=-2 \log L+k \log (N)$, where $k$ is the number of regressors and $N$ is the number of observations. The McFadden- $\mathrm{R}^{2}$ is the pseudo- $\mathrm{R}^{2}=1-\operatorname{LogL} / \log \mathrm{L}_{0}$, where $\operatorname{LogL} \mathrm{L}_{0}$ is the $\log$-likelihood of the model with only a constant term. The FE-test reports the Hausman test statistic and respective p-value (in square brackets) for the comparison between the ordinary and the fixed effects logit (for details, see Greene, 2012, pp. 763-764); the RE-test reports the LR-test statistic and respective p-value (in square brackets) for the comparison between the ordinary and the random effects logit; and the REvsFE-test reports the Hausman test statistic and respective p-value (in square brackets) for the comparison between the random and the fixed effects logit. Decade-dummies are included in all estimations to account for time effects. All economic variables are lagged one period to avoid simultaneity problems. In columns 7 and 8 are reported the results from instrumental variables estimations, where TotCapInflows, Cred/Deposits, IRspread and RealGDPgr are instrumented with their respective 4 lags and a dummy for periods of banking crises. The results from the respective endogeneity tests (Wald exogeneity test for the IV-Probit and Durbin-WuHausman for the FE IV-Logit) are reported at the bottom of the table (respective p-value in square-brackets). 
Table 2. Sensitivity analysis I: Economic determinants

\begin{tabular}{|c|c|c|c|c|c|c|c|c|c|}
\hline MgEffects & (1) & $(2)$ & (3) & (4) & (5) & $(6)$ & (7) & (8) & (9) \\
\hline TotCapInflows & & & & $\begin{array}{c}0.0239^{* *} \\
(0.0117)\end{array}$ & $\begin{array}{c}0.0233 * * \\
(0.0119)\end{array}$ & $\begin{array}{c}0.0215^{* *} \\
(0.0108)\end{array}$ & $\begin{array}{c}0.0220 * * \\
(0.0110)\end{array}$ & $\begin{array}{c}0.0209 * * \\
(0.0104)\end{array}$ & $\begin{array}{c}0.0210 * * \\
(0.0106)\end{array}$ \\
\hline CapInflowsFDI & $\begin{array}{l}-0.0039 \\
(0.0216)\end{array}$ & & & & & & & & \\
\hline CapInflowsPI & & $\begin{array}{l}0.0267^{*} \\
(0.0156)\end{array}$ & & & & & & & \\
\hline CapInflowsOI & & & $\begin{array}{c}0.0549 * * \\
(0.0255)\end{array}$ & & & & & & \\
\hline Credit/Deposits & $\begin{array}{c}0.0142 * * * \\
(0.0029)\end{array}$ & $\begin{array}{c}0.0140 * * * \\
(0.0029)\end{array}$ & $\begin{array}{c}0.0145^{* * *} * \\
(0.0029)\end{array}$ & & & $\begin{array}{c}0.0140 * * * \\
(0.0029)\end{array}$ & $\begin{array}{c}0.0142 * * * \\
(0.0029)\end{array}$ & $\begin{array}{c}0.0144 * * * \\
(0.0031)\end{array}$ & $\begin{array}{c}0.0148 * * * \\
(0.0030)\end{array}$ \\
\hline Credit/GDP & & & & $\begin{array}{c}0.0005 \\
(0.0007)\end{array}$ & & & & & \\
\hline RealCredit/Pop & & & & & $\begin{array}{c}0.0033 * * * \\
(0.0007)\end{array}$ & & & & \\
\hline IRspread & $\begin{array}{l}-0.0042 * \\
(0.0022)\end{array}$ & $\begin{array}{l}-0.0042 * \\
(0.0022)\end{array}$ & $\begin{array}{c}-0.0043^{* *} \\
(0.0021)\end{array}$ & $\begin{array}{c}-0.0058^{* *} \\
(0.0024)\end{array}$ & $\begin{array}{c}-0.0073^{* * * *} \\
(0.0026)\end{array}$ & & $\begin{array}{c}-0.0043^{* *} \\
(0.0021)\end{array}$ & $\begin{array}{l}-0.0036^{*} \\
(0.0020)\end{array}$ & $\begin{array}{l}-0.0038^{*} \\
(0.0021)\end{array}$ \\
\hline LendRate & & & & & & $\begin{array}{c}-0.0042 * * \\
(0.0021)\end{array}$ & & & \\
\hline DepositsRate & & & & & & $\begin{array}{c}0.0064^{* *} \\
(0.0030)\end{array}$ & & & \\
\hline RealGDPgr & $\begin{array}{c}0.0161 * * * \\
(0.0038)\end{array}$ & $\begin{array}{c}0.0157 * * * \\
(0.0038)\end{array}$ & $\begin{array}{c}0.0157 * * * \\
(0.0039)\end{array}$ & $\begin{array}{c}0.0114 * * * \\
(0.0038)\end{array}$ & $\begin{array}{c}0.0160 * * * \\
(0.0041)\end{array}$ & $\begin{array}{c}0.0157 * * * \\
(0.0038)\end{array}$ & $\begin{array}{c}0.0156^{* * *} \\
(0.0039)\end{array}$ & $\begin{array}{c}0.0146^{* * *} \\
(0.0038)\end{array}$ & $\begin{array}{c}0.0130 * * * \\
(0.0040)\end{array}$ \\
\hline Inflation & $\begin{array}{c}0.0004 \\
(0.0016)\end{array}$ & $\begin{array}{c}0.0004 \\
(0.0016)\end{array}$ & $\begin{array}{c}0.0004 \\
(0.0016)\end{array}$ & $\begin{array}{c}-0.0002 \\
(0.0017)\end{array}$ & $\begin{array}{c}0.0002 \\
(0.0018)\end{array}$ & $\begin{array}{c}-0.0005 \\
(0.0018)\end{array}$ & $\begin{array}{c}0.0004 \\
(0.0016)\end{array}$ & $\begin{array}{c}0.0005 \\
(0.0015)\end{array}$ & $\begin{array}{c}0.0005 \\
(0.0015)\end{array}$ \\
\hline CurrAccount & $\begin{array}{c}-0.0338 * * * \\
(0.0048)\end{array}$ & $\begin{array}{c}-0.0338 * * * \\
(0.0048)\end{array}$ & $\begin{array}{c}-0.0344 * * * \\
(0.0047)\end{array}$ & $\begin{array}{c}-0.0399 * * * \\
(0.0046)\end{array}$ & $\begin{array}{c}-0.0428 * * * \\
(0.0037)\end{array}$ & $\begin{array}{c}-0.0331 * * * \\
(0.0049)\end{array}$ & $\begin{array}{c}-0.0340 * * * \\
(0.0048)\end{array}$ & $\begin{array}{c}-0.0319 * * * \\
(0.0055)\end{array}$ & $\begin{array}{c}-0.0332 * * * \\
(0.0051)\end{array}$ \\
\hline Openness & $\begin{array}{c}0.3275^{* * * *} \\
(0.0505)\end{array}$ & $\begin{array}{c}0.3311^{* * * *} \\
(0.0507)\end{array}$ & $\begin{array}{c}0.3248^{* * *} \\
(0.0514)\end{array}$ & $\begin{array}{c}0.3551 * * * * \\
(0.0532)\end{array}$ & $\begin{array}{c}0.3065^{* * *} \\
(0.0581)\end{array}$ & $\begin{array}{c}0.3310 * * * \\
(0.0507)\end{array}$ & $\begin{array}{c}0.3335^{* * *} \\
(0.0516)\end{array}$ & $\begin{array}{c}0.3132 * * * \\
(0.0539)\end{array}$ & $\begin{array}{c}0.3309 * * * \\
(0.0510)\end{array}$ \\
\hline ApprecREER & $\begin{array}{c}0.3172^{* * *} \\
(0.1458)\end{array}$ & $\begin{array}{c}0.3135^{* * *} \\
(0.1451)\end{array}$ & $\begin{array}{c}0.3106^{* * *} \\
(0.1480)\end{array}$ & $\begin{array}{c}0.3658 * * \\
(0.1571)\end{array}$ & $\begin{array}{c}0.4018^{* *} \\
(0.1669)\end{array}$ & $\begin{array}{c}0.2939 * * \\
(0.1441)\end{array}$ & $\begin{array}{c}0.3104^{* *} \\
(0.1458)\end{array}$ & $\begin{array}{c}0.3202 * * \\
(0.1393)\end{array}$ & $\begin{array}{c}0.3386^{* *} \\
(0.1438)\end{array}$ \\
\hline ExchRateFlex & $\begin{array}{l}-0.0081 \\
(0.0150)\end{array}$ & $\begin{array}{l}-0.0086 \\
(0.0150)\end{array}$ & $\begin{array}{l}-0.0086 \\
(0.0152)\end{array}$ & $\begin{array}{c}0.0058 \\
(0.0147)\end{array}$ & $\begin{array}{l}-0.0092 \\
(0.0163)\end{array}$ & $\begin{array}{l}-0.0104 \\
(0.0151)\end{array}$ & & $\begin{array}{l}-0.0125 \\
(0.0146)\end{array}$ & $\begin{array}{l}-0.0095 \\
(0.0148)\end{array}$ \\
\hline ExchRateFlexF & & & & & & & $\begin{array}{c}-0.0027 \\
(0.0045)\end{array}$ & & \\
\hline Debt & & & & & & & & $\begin{array}{l}0.0056^{*} \\
(0.0032)\end{array}$ & \\
\hline GovBS & & & & & & & & & $\begin{array}{l}-0.0082^{*} \\
(0.0042)\end{array}$ \\
\hline YrBefElection & $\begin{array}{l}-0.0193 \\
(0.0176)\end{array}$ & $\begin{array}{l}-0.0169 \\
(0.0175)\end{array}$ & $\begin{array}{l}-0.0183 \\
(0.0178)\end{array}$ & $\begin{array}{l}-0.0147 \\
(0.0188)\end{array}$ & $\begin{array}{l}-0.0160 \\
(0.0198)\end{array}$ & $\begin{array}{l}-0.0168 \\
(0.0173)\end{array}$ & $\begin{array}{l}-0.0163 \\
(0.0176)\end{array}$ & $\begin{array}{l}-0.0118 \\
(0.0166)\end{array}$ & $\begin{array}{l}-0.0119 \\
(0.0172)\end{array}$ \\
\hline RightGov & $\begin{array}{c}-0.0637 * * * \\
(0.0201)\end{array}$ & $\begin{array}{c}-0.0634 * * * \\
(0.0200)\end{array}$ & $\begin{array}{c}-0.0655 * * * \\
(0.0204)\end{array}$ & $\begin{array}{c}-0.0566^{* * * *} \\
(0.0207)\end{array}$ & $\begin{array}{c}-0.0458^{* *} \\
(0.0209)\end{array}$ & $\begin{array}{c}-0.0628 * * * * \\
(0.0199)\end{array}$ & $\begin{array}{c}-0.0648 * * * \\
(0.0205)\end{array}$ & $\begin{array}{c}-0.0636^{* * * *} \\
(0.0208)\end{array}$ & $\begin{array}{c}-0.0698^{* * * *} \\
(0.0206)\end{array}$ \\
\hline MajorityGov & $\begin{array}{c}0.0145 \\
(0.0194)\end{array}$ & $\begin{array}{c}0.0145 \\
(0.0193)\end{array}$ & $\begin{array}{c}0.0142 \\
(0.0198)\end{array}$ & $\begin{array}{c}0.0223 \\
(0.0213)\end{array}$ & $\begin{array}{c}0.0030 \\
(0.0230)\end{array}$ & $\begin{array}{c}0.0134 \\
(0.0191)\end{array}$ & $\begin{array}{c}0.0144 \\
(0.0195)\end{array}$ & $\begin{array}{c}0.0140 \\
(0.0189)\end{array}$ & $\begin{array}{c}0.0180 \\
(0.0192)\end{array}$ \\
\hline NGovChanges & $\begin{array}{c}-0.0292^{* *} \\
(0.0140)\end{array}$ & $\begin{array}{c}-0.0282^{* *} \\
(0.0139)\end{array}$ & $\begin{array}{c}-0.0292^{* *} \\
(0.0142)\end{array}$ & $\begin{array}{c}-0.0270^{*} \\
(0.0147)\end{array}$ & $\begin{array}{l}-0.0292 * \\
(0.0152)\end{array}$ & $\begin{array}{c}-0.0290 * * \\
(0.0139)\end{array}$ & $\begin{array}{c}-0.0281^{* *} \\
(0.0140)\end{array}$ & $\begin{array}{c}-0.0250^{*} \\
(0.0136)\end{array}$ & $\begin{array}{l}-0.0230^{*} \\
(0.0138)\end{array}$ \\
\hline$C B I$ & $\begin{array}{c}-0.1897^{* *} \\
(0.0884)\end{array}$ & $\begin{array}{c}-0.1885^{* *} \\
(0.0881)\end{array}$ & $\begin{array}{c}-0.1933^{* *} \\
(0.0895)\end{array}$ & $\begin{array}{c}-0.1574 * * \\
(0.0818)\end{array}$ & $\begin{array}{c}-0.1762 * * \\
(0.0874)\end{array}$ & $\begin{array}{c}-0.1867 * * \\
(0.0877)\end{array}$ & $\begin{array}{c}-0.1920 * * \\
(0.0889)\end{array}$ & $\begin{array}{c}-0.1898^{* *} \\
(0.0869)\end{array}$ & $\begin{array}{c}-0.1905^{* *} \\
(0.0873)\end{array}$ \\
\hline$M U$ & $\begin{array}{c}0.1985 * * * \\
(0.0559)\end{array}$ & $\begin{array}{c}0.1947 * * * \\
(0.0555)\end{array}$ & $\begin{array}{c}0.2012 * * * \\
(0.0564)\end{array}$ & $\begin{array}{c}0.1589 * * * \\
(0.0528)\end{array}$ & $\begin{array}{c}0.1873 * * * \\
(0.0546)\end{array}$ & $\begin{array}{c}0.1914 * * * \\
(0.0553)\end{array}$ & $\begin{array}{c}0.1884^{* * *} \\
(0.0570)\end{array}$ & $\begin{array}{c}0.1835^{* * *} \\
(0.0558)\end{array}$ & $\begin{array}{c}0.1893^{* * *} \\
(0.0551)\end{array}$ \\
\hline \#Observations & 3161 & 3161 & 3157 & 3204 & 3204 & 3157 & 3157 & 3072 & 3061 \\
\hline \#Countries & 47 & 47 & 47 & 47 & 47 & 47 & 47 & 46 & 46 \\
\hline $\log L$ & -1157.5 & -1156.0 & -1154.3 & -1193.1 & -1170.9 & -1154.4 & -1155.0 & -1112.0 & -1115.8 \\
\hline SBIC & 2468.1 & 2465.1 & 2461.7 & 2539.6 & 2495.2 & 2470.0 & 2463.1 & 2400.6 & 2392.1 \\
\hline McFadden- $\mathrm{R}^{2}$ & 0.162 & 0.163 & 0.163 & 0.150 & 0.166 & 0.163 & 0.163 & 0.174 & 0.168 \\
\hline
\end{tabular}

Notes: See Table 1. Fixed effects logit estimations for the likelihood of credit booms considering the Gourinchas et al. (2001) criteria with standard deviation threshold equal to 1.5 . Standard errors are reported in parentheses for each marginal effect; ***, **,* - statistically significant at 1\%,5\% and 10\% level, respectively. Decade-dummies are included in all estimations to account for time effects. All economic variables are lagged one period to avoid simultaneity problems. CapInflowsFDI, CapInflowsPI and CapInflowsOI represent, respectively, foreign direct investment, portfolio investment and other investment liability flows as percentage of GDP; Credit/GDP is the ratio of private credit to GDP; RealCredit/Pop is the ratio of private credit to the population; LendRate and DepositsRate are the average interest rates on loans (lending) and deposits, respectively; ExchRateFlexF is an alternative fine classification for the exchange rate flexibility ranging from 0 to 15 (see Reinhart and Rogoff, 2004; and Ilzetzky et al., 2009). Debt and GovBS correspond to gross general government public debt and government budget surplus (deficit) as a percentage of GDP, respectively, obtained from the WDI. 
Table 3. Sensitivity analysis II: Political determinants

\begin{tabular}{|c|c|c|c|c|c|c|c|}
\hline MgEffects & $(1)$ & $(2)$ & (3) & (4) & (5) & $(6)$ & (7) \\
\hline TotCapInflows & $\begin{array}{c}0.0223 * * \\
(0.0109)\end{array}$ & $\begin{array}{c}0.0223 * * \\
(0.0109)\end{array}$ & $\begin{array}{c}0.0221^{* *} \\
(0.0108)\end{array}$ & $\begin{array}{c}0.0195 * * \\
(0.0099)\end{array}$ & $\begin{array}{c}0.0221^{* *} \\
(0.0109)\end{array}$ & $\begin{array}{c}0.0220 * * \\
(0.0108)\end{array}$ & $\begin{array}{c}0.0174 * * \\
(0.0088)\end{array}$ \\
\hline Credit/Deposits & $\begin{array}{c}0.0138 * * * \\
(0.0029)\end{array}$ & $\begin{array}{c}0.0138 * * * \\
(0.0029)\end{array}$ & $\begin{array}{c}0.0137 * * * \\
(0.0029)\end{array}$ & $\begin{array}{c}0.0132 * * * \\
(0.0029)\end{array}$ & $\begin{array}{c}0.0144 * * * \\
(0.0029)\end{array}$ & $\begin{array}{c}0.0125 * * * \\
(0.0028)\end{array}$ & $\begin{array}{c}0.0090 * * * \\
(0.0029)\end{array}$ \\
\hline IRspread & $\begin{array}{c}-0.0042 * * \\
(0.0021)\end{array}$ & $\begin{array}{c}-0.0042 * * \\
(0.0021)\end{array}$ & $\begin{array}{l}-0.0041^{*} \\
(0.0021)\end{array}$ & $\begin{array}{c}-0.0041 * * \\
(0.0021)\end{array}$ & $\begin{array}{c}-0.0047 * * \\
(0.0022)\end{array}$ & $\begin{array}{c}-0.0045^{* *} \\
(0.0022)\end{array}$ & $\begin{array}{l}-0.0029^{*} \\
(0.0017)\end{array}$ \\
\hline RealGDPgr & $\begin{array}{c}0.0150 * * * \\
(0.0038)\end{array}$ & $\begin{array}{c}0.0150 * * * \\
(0.0038)\end{array}$ & $\begin{array}{c}0.0150 * * * \\
(0.0038)\end{array}$ & $\begin{array}{c}0.0156^{* * *} \\
(0.0039)\end{array}$ & $\begin{array}{c}0.0144 * * * \\
(0.0038)\end{array}$ & $\begin{array}{c}0.0151^{* * *} \\
(0.0037)\end{array}$ & $\begin{array}{c}0.0096^{* * *} \\
(0.0036)\end{array}$ \\
\hline Inflation & $\begin{array}{c}0.0004 \\
(0.0015)\end{array}$ & $\begin{array}{c}0.0004 \\
(0.0016)\end{array}$ & $\begin{array}{c}0.0003 \\
(0.0015)\end{array}$ & $\begin{array}{c}0.0005 \\
(0.0014)\end{array}$ & $\begin{array}{c}0.0003 \\
(0.0016)\end{array}$ & $\begin{array}{c}0.0006 \\
(0.0015)\end{array}$ & $\begin{array}{c}0.0001 \\
(0.0012)\end{array}$ \\
\hline CurrAccount & $\begin{array}{c}-0.0332 * * * \\
(0.0049)\end{array}$ & $\begin{array}{c}-0.0333 * * * \\
(0.0049)\end{array}$ & $\begin{array}{c}-0.0330 * * * \\
(0.0049)\end{array}$ & $\begin{array}{c}-0.0308 * * * \\
(0.0053)\end{array}$ & $\begin{array}{c}-0.0334 * * * \\
(0.0047)\end{array}$ & $\begin{array}{c}-0.0306^{* * *} \\
(0.0049)\end{array}$ & $\begin{array}{c}-0.0258 * * * \\
(0.0065)\end{array}$ \\
\hline Openness & $\begin{array}{c}0.3277 * * * \\
(0.0507)\end{array}$ & $\begin{array}{c}0.3285 * * * \\
(0.0506)\end{array}$ & $\begin{array}{c}0.3254 * * * \\
(0.0506)\end{array}$ & $\begin{array}{c}0.2916^{* * *} \\
(0.0501)\end{array}$ & $\begin{array}{c}0.3465 * * * \\
(0.0509)\end{array}$ & $\begin{array}{c}0.3144 * * * \\
(0.0498)\end{array}$ & $\begin{array}{c}0.2709 * * * \\
(0.0605)\end{array}$ \\
\hline ApprecREER & $\begin{array}{l}0.3042 * * \\
(0.1433)\end{array}$ & $\begin{array}{c}0.3041 * * \\
(0.1438)\end{array}$ & $\begin{array}{l}0.3084 * * \\
(0.1426)\end{array}$ & $\begin{array}{l}0.2467^{*} \\
(0.1319)\end{array}$ & $\begin{array}{l}0.3012 * * \\
(0.1441)\end{array}$ & $\begin{array}{l}0.2646^{*} \\
(0.1392)\end{array}$ & $\begin{array}{l}0.2407 * * \\
(0.1192)\end{array}$ \\
\hline ExchRateFlex & $\begin{array}{l}-0.0097 \\
(0.0148)\end{array}$ & $\begin{array}{l}-0.0096 \\
(0.0148)\end{array}$ & $\begin{array}{l}-0.0096 \\
(0.0147)\end{array}$ & $\begin{array}{l}-0.0087 \\
(0.0138)\end{array}$ & $\begin{array}{l}-0.0080 \\
(0.0149)\end{array}$ & $\begin{array}{l}-0.0080 \\
(0.0142)\end{array}$ & $\begin{array}{l}-0.0070 \\
(0.0116)\end{array}$ \\
\hline YrBefElection & & & & $\begin{array}{l}-0.0140 \\
(0.0159)\end{array}$ & $\begin{array}{l}-0.0155 \\
(0.0173)\end{array}$ & $\begin{array}{l}-0.0050 \\
(0.0154)\end{array}$ & $\begin{array}{c}0.0030 \\
(0.0118)\end{array}$ \\
\hline ElectionQtr & $\begin{array}{l}-0.0086 \\
(0.0285)\end{array}$ & & & & & & \\
\hline Election Yr & & $\begin{array}{c}-0.0007 \\
(0.0158)\end{array}$ & & & & & \\
\hline YrAftElection & & & $\begin{array}{l}-0.0140 \\
(0.0179)\end{array}$ & & & & \\
\hline RightGov & $\begin{array}{c}-0.0625^{* * *} \\
(0.0199)\end{array}$ & $\begin{array}{c}-0.0627 * * * \\
(0.0199)\end{array}$ & $\begin{array}{c}-0.0620 * * * \\
(0.0199)\end{array}$ & & $\begin{array}{c}-0.0616 * * * \\
(0.0199)\end{array}$ & $\begin{array}{c}-0.0585 * * * \\
(0.0196)\end{array}$ & $\begin{array}{c}-0.0463 * * \\
(0.0181)\end{array}$ \\
\hline CentreGov & & & & $\begin{array}{c}0.1338 * * * \\
(0.0345)\end{array}$ & & & \\
\hline LeftGov & & & & $\begin{array}{c}0.0372 * * \\
(0.0172)\end{array}$ & & & \\
\hline MajorityGov & $\begin{array}{c}0.0150 \\
(0.0190)\end{array}$ & $\begin{array}{c}0.0149 \\
(0.0191)\end{array}$ & $\begin{array}{c}0.0155 \\
(0.0189)\end{array}$ & $\begin{array}{c}0.0152 \\
(0.0175)\end{array}$ & & $\begin{array}{c}0.0211 \\
(0.0186)\end{array}$ & \\
\hline SPMajGov & & & & & $\begin{array}{c}-0.0353 \\
(0.0290)\end{array}$ & & \\
\hline CoalMajGov & & & & & $\begin{array}{l}0.0355^{*} \\
(0.0210)\end{array}$ & & \\
\hline NGovChanges & $\begin{array}{l}-0.0222 * \\
(0.0129)\end{array}$ & $\begin{array}{l}-0.0231 * \\
(0.0126)\end{array}$ & $\begin{array}{l}-0.0179 * \\
(0.0103)\end{array}$ & $\begin{array}{c}-0.0257 * * \\
(0.0130)\end{array}$ & $\begin{array}{c}-0.0276 * * \\
(0.0138)\end{array}$ & & \\
\hline PartyTenure & & & & & & $\begin{array}{c}0.0001 \\
(0.0003)\end{array}$ & \\
\hline GovStability & & & & & & & $\begin{array}{l}0.0060^{*} \\
(0.0032)\end{array}$ \\
\hline$C B I$ & $\begin{array}{c}-0.1879 * * \\
(0.0878)\end{array}$ & $\begin{array}{c}-0.1883^{* *} \\
(0.0879)\end{array}$ & $\begin{array}{c}-0.1870 * * \\
(0.0875)\end{array}$ & $\begin{array}{c}-0.1912 * * \\
(0.0867)\end{array}$ & $\begin{array}{c}-0.2049 * * \\
(0.0889)\end{array}$ & $\begin{array}{c}-0.2048^{* *} \\
(0.0896)\end{array}$ & $\begin{array}{c}-0.1424 * * \\
(0.0719)\end{array}$ \\
\hline$M U$ & $\begin{array}{c}0.1901 * * * \\
(0.0551)\end{array}$ & $\begin{array}{c}0.1905 * * * \\
(0.0551)\end{array}$ & $\begin{array}{c}0.1889 * * * \\
(0.0550)\end{array}$ & $\begin{array}{c}0.1883 * * * \\
(0.0558)\end{array}$ & $\begin{array}{c}0.2032 * * * \\
(0.0559)\end{array}$ & $\begin{array}{c}0.1837 * * * \\
(0.0550)\end{array}$ & $\begin{array}{l}0.1216 * * \\
(0.0507)\end{array}$ \\
\hline \#Observations & 3157 & 3157 & 3157 & 3157 & 3157 & 3189 & 2981 \\
\hline \#Countries & 47 & 47 & 47 & 47 & 47 & 47 & 46 \\
\hline $\log L$ & -1155.4 & -1155.5 & -1155.2 & -1149.5 & -1152.1 & -1190.3 & -1117.5 \\
\hline SBIC & 2464.0 & 2464.1 & 2463.4 & 2460.2 & 2465.3 & 2534.0 & 2378.9 \\
\hline McFadden- $\mathrm{R}^{2}$ & 0.162 & 0.162 & 0.162 & 0.166 & 0.165 & 0.149 & 0.162 \\
\hline
\end{tabular}


Table 4. Sensitivity analysis III: Central Bank independence

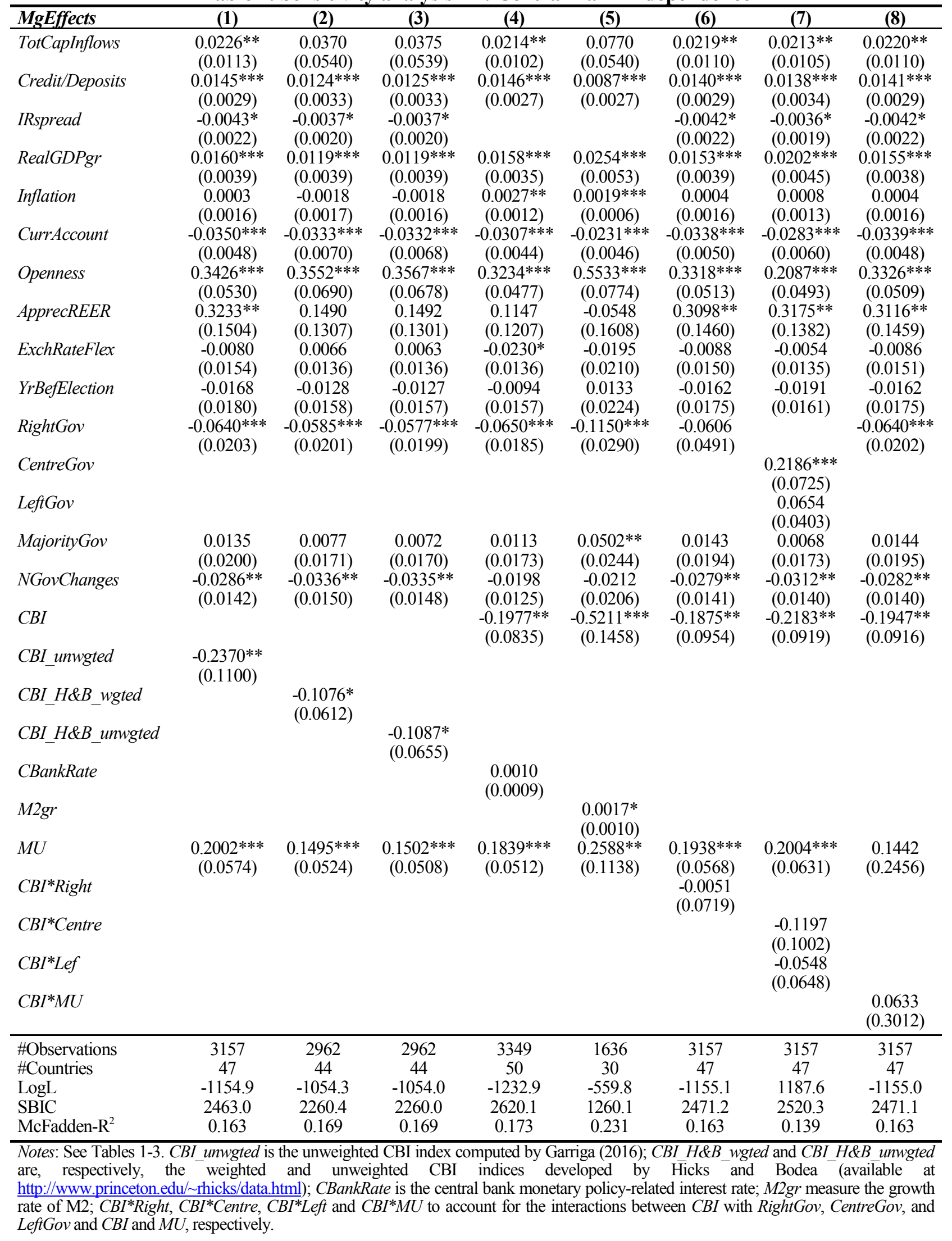


Table 5. Robustness checks I: Developed versus Developing countries

\begin{tabular}{|c|c|c|c|c|c|c|c|}
\hline \multirow[b]{2}{*}{ MgEffects } & \multirow{2}{*}{$\begin{array}{l}\text { All } \\
(1)\end{array}$} & \multirow{2}{*}{$\begin{array}{c}\text { Developed } \\
\text { (2) }\end{array}$} & \multicolumn{5}{|c|}{ Developing } \\
\hline & & & (3) & (4) & (5) & (6) & (7) \\
\hline \multirow[t]{2}{*}{ TotCapInflows } & $0.0184 *$ & $0.0231 * *$ & 0.2166 & 0.2265 & 0.2379 & 0.2224 & 0.1628 \\
\hline & $(0.0099)$ & $(0.0112)$ & $(0.1617)$ & $(0.1563)$ & $(0.1547)$ & $(0.1642)$ & $(0.1409)$ \\
\hline \multirow[t]{2}{*}{ Credit/Deposits } & $0.0135 * * *$ & 0.0014 & $0.0219 * * *$ & $0.0230 * * *$ & $0.0220 * * *$ & $0.0218 * * *$ & $0.0198 * * *$ \\
\hline & $(0.0030)$ & $(0.0054)$ & $(0.0028)$ & $(0.0030)$ & $(0.0028)$ & $(0.0028)$ & $(0.0026)$ \\
\hline \multirow[t]{2}{*}{ IRspread } & $-0.0037^{*}$ & -0.0079 & $-0.0066^{* * *}$ & -0.0027 & $-0.0043^{* *}$ & $-0.0066^{* * *}$ & $-0.0058^{* * *}$ \\
\hline & $(0.0020)$ & $(0.0073)$ & $(0.0016)$ & $(0.0024)$ & $(0.0020)$ & $(0.0016)$ & $(0.0016)$ \\
\hline \multirow[t]{2}{*}{ RealGDPgr } & $0.0147 * * *$ & $0.0192 * * *$ & $0.0107 * *$ & $0.0126^{* *}$ & $0.0120 * *$ & $0.0114 * *$ & $0.0080 *$ \\
\hline & $(0.0038)$ & $(0.0057)$ & $(0.0052)$ & $(0.0052)$ & $(0.0053)$ & $(0.0053)$ & $(0.0046)$ \\
\hline \multirow[t]{2}{*}{ Inflation } & 0.0008 & 0.0063 & $0.0080 * * *$ & $0.0087 * * *$ & $0.0104 * * *$ & $0.0081 * * *$ & $0.0064 * * *$ \\
\hline & $(0.0014)$ & $(0.0043)$ & $(0.0020)$ & $(0.0020)$ & $(0.0022)$ & $(0.0020)$ & $(0.0018)$ \\
\hline \multirow[t]{2}{*}{ CurrAccount } & $-0.0303 * * *$ & $-0.0446 * * *$ & $-0.0197 * * *$ & $-0.0200 * * *$ & $-0.0177 * * *$ & $-0.0215 * * *$ & $-0.0196^{* * *}$ \\
\hline & $(0.0054)$ & $(0.0038)$ & $(0.0045)$ & $(0.0046)$ & $(0.0045)$ & $(0.0054)$ & $(0.0041)$ \\
\hline \multirow[t]{2}{*}{ Openness } & $0.2421 * * *$ & $0.3111 * * *$ & $0.5027 * * *$ & $0.4393 * * *$ & $0.4746^{* * *}$ & $0.5042 * * *$ & $0.3953 * * *$ \\
\hline & $(0.0567)$ & $(0.0798)$ & $(0.1425)$ & $(0.1303)$ & $(0.1457)$ & $(0.1412)$ & $(0.1337)$ \\
\hline \multirow[t]{2}{*}{ ApprecREER } & $0.2585^{*}$ & $0.6544 * *$ & 0.2303 & 0.2146 & $0.2922 *$ & 0.2261 & 0.1675 \\
\hline & $(0.1344)$ & $(0.2618)$ & $(0.1673)$ & $(0.1654)$ & $(0.1711)$ & $(0.1691)$ & $(0.1521)$ \\
\hline \multirow[t]{2}{*}{ ExchRateFlex } & -0.0091 & -0.0222 & -0.0166 & -0.0165 & -0.0104 & -0.0188 & -0.0096 \\
\hline & $(0.0138)$ & $(0.0226)$ & $(0.0168)$ & $(0.0164)$ & $(0.0170)$ & $(0.0174)$ & $(0.0148)$ \\
\hline \multirow{2}{*}{ YrBefElection } & -0.0154 & -0.0276 & -0.0018 & -0.0077 & -0.0040 & -0.0049 & 0.0090 \\
\hline & $(0.0160)$ & $(0.0240)$ & $(0.0259)$ & $(0.0254)$ & $(0.0259)$ & $(0.0266)$ & $(0.0235)$ \\
\hline \multirow{2}{*}{ RightGov } & $-0.0594 * * *$ & -0.0373 & $-0.1075 * * *$ & -0.0303 & -0.0046 & $-0.0969 * * *$ & 0.0741 \\
\hline & $(0.0195)$ & $(0.0251)$ & $(0.0289)$ & $(0.0421)$ & $(0.0497)$ & $(0.0334)$ & $(0.0585)$ \\
\hline \multirow[t]{2}{*}{ MajorityGov } & 0.0090 & $-0.0895 * * *$ & $0.1206 * * *$ & $0.1263 * * *$ & $0.1198 * * *$ & $0.1217 * * *$ & $0.1008 * * *$ \\
\hline & $(0.0177)$ & $(0.0285)$ & $(0.0274)$ & $(0.0263)$ & $(0.0276)$ & $(0.0274)$ & $(0.0254)$ \\
\hline \multirow[t]{2}{*}{ NGovChanges } & $-0.0256^{*}$ & $-0.0454 *$ & -0.0261 & -0.0317 & $-0.0360 *$ & -0.0290 & -0.0179 \\
\hline & $(0.0131)$ & $(0.0269)$ & $(0.0205)$ & $(0.0203)$ & $(0.0212)$ & $(0.0211)$ & $(0.0189)$ \\
\hline \multirow[t]{2}{*}{$C B I$} & $-0.1754 * *$ & $-0.1456^{* *}$ & $-0.7376^{* * * *}$ & $-0.7006^{* * *}$ & $-0.7986^{* * *}$ & $-0.7154 * * *$ & $-0.6884 * * *$ \\
\hline & $(0.0848)$ & $(0.0646)$ & $(0.1040)$ & $(0.1312)$ & (0.1069) & $(0.1126)$ & $(0.1078)$ \\
\hline \multirow[t]{2}{*}{$M U$} & $0.1661 * * *$ & $0.1905 * * *$ & & & & & \\
\hline & $(0.0542)$ & $(0.0609)$ & & & & & \\
\hline Developed & $0.1135^{*}$ & & & & & & \\
\hline Right*IRspread & $(0.0619)$ & & & $-0.0060 * *$ & & & \\
\hline Right*IRspread & & & & $\begin{array}{c}-0.0060 * * \\
(0.0024)\end{array}$ & & & \\
\hline Right*Inflation & & & & & $-0.0136^{* *}$ & & \\
\hline & & & & & $(0.0054)$ & & \\
\hline $\operatorname{Right}^{*}$ CurrAcc & & & & & & $0.0148 * *$ & \\
\hline & & & & & & $(0.0067)$ & \\
\hline Right $^{*}$ Dec 80 & & & & & & & -1.3144 \\
\hline & & & & & & & $(2.3026)$ \\
\hline Right $*$ Dec 90 & & & & & & & $-0.1289 *$ \\
\hline & & & & & & & $(0.0670)$ \\
\hline Right*Dec00 & & & & & & & $-0.2994 * * *$ \\
\hline & & & & & & & $(0.0725)$ \\
\hline Right $^{*}$ Dec10 & & & & & & & -1.2194 \\
\hline & & & & & & & $(1.0100)$ \\
\hline \#Observations & 3157 & 2296 & 856 & 856 & 856 & 856 & 856 \\
\hline \#Countries & 47 & 31 & 16 & 16 & 16 & 16 & 16 \\
\hline \#Episodes & 88 & 61 & 27 & 27 & 27 & 27 & 27 \\
\hline $\log L$ & 1155.0 & -821.6 & -267.8 & -264.7 & -264.1 & -267.6 & -259.1 \\
\hline SBIC & 2471.1 & 1790.2 & 657.1 & 657.8 & 656.4 & 663.4 & 659.9 \\
\hline McFadden- $\mathrm{R}^{2}$ & 0.163 & 0.158 & 0.334 & 0.342 & 0.344 & 0.335 & 0.356 \\
\hline
\end{tabular}

Notes: See Tables 1-4. Estimations considering Gourinchas et al. (2001) criteria with standard deviation threshold equal to 1.5. The number of credit boom episodes is reported at the bottom of the table for each group of countries. A fixed effects logit is estimated for the entire sample with the dummy Developed and the sub-samples of developed and developing countries. 
Table 6. Robustness checks II: Monetary Union and Global Financial Crisis

\begin{tabular}{|c|c|c|c|c|c|c|}
\hline \multirow[b]{2}{*}{ MgEffects } & \multirow{2}{*}{$\begin{array}{l}\text { MU } \\
\text { (1) }\end{array}$} & \multirow{2}{*}{$\begin{array}{c}\text { Non-MU } \\
\text { (2) }\end{array}$} & \multicolumn{3}{|c|}{ Before GFC } & \multirow{2}{*}{$\begin{array}{c}\text { Dummy GFC } \\
\text { (6) }\end{array}$} \\
\hline & & & $\begin{array}{l}\text { All } \\
(3) \\
\end{array}$ & $\begin{array}{c}\text { Developed } \\
(4) \\
\end{array}$ & $\begin{array}{c}\text { Developing } \\
\text { (5) } \\
\end{array}$ & \\
\hline \multirow[t]{2}{*}{ TotCapInflows } & $0.0189 * * *$ & 0.0882 & $0.0611 * *$ & $0.0426 * *$ & 0.1607 & $0.0286 * *$ \\
\hline & $(0.0063)$ & $(0.0604)$ & $(0.0248)$ & $(0.0201)$ & $(0.1173)$ & $(0.0125)$ \\
\hline \multirow[t]{2}{*}{ Credit/Deposits } & $0.0273 * *$ & $0.0151 * * *$ & $0.0157 * * *$ & -0.0060 & $0.0098 *$ & $0.0164 * * *$ \\
\hline & $(0.0124)$ & $(0.0037)$ & $(0.0032)$ & $(0.0057)$ & $(0.0059)$ & $(0.0033)$ \\
\hline \multirow[t]{2}{*}{ IRspread } & 0.0037 & -0.0027 & -0.0045 & $-0.0119 *$ & $-0.0016^{*}$ & -0.0023 \\
\hline & $(0.0065)$ & $(0.0022)$ & $(0.0029)$ & $(0.0072)$ & $(0.0009)$ & $(0.0021)$ \\
\hline \multirow[t]{2}{*}{ RealGDPgr } & $0.0059 *$ & $0.0205 * * *$ & $0.0166 * * *$ & $0.0142 *$ & $0.0059 *$ & $0.0244 * * *$ \\
\hline & $(0.0032)$ & $(0.0048)$ & $(0.0062)$ & $(0.0075)$ & $(0.0032)$ & $(0.0045)$ \\
\hline \multirow[t]{2}{*}{ Inflation } & $0.0571 * * *$ & -0.0011 & -0.0032 & 0.0106 & $0.0015^{*}$ & 0.0009 \\
\hline & $(0.0120)$ & $(0.0018)$ & $(0.0023)$ & $(0.0140)$ & $(0.0009)$ & $(0.0016)$ \\
\hline \multirow{2}{*}{ CurrAccount } & $-0.0305 * * *$ & $-0.0309 * * *$ & $-0.0448 * * *$ & $-0.0444 * * *$ & $-0.0062 *$ & $-0.0341 * * *$ \\
\hline & $(0.0032)$ & $(0.0057)$ & $(0.0049)$ & $(0.0088)$ & $(0.0034)$ & $(0.0050)$ \\
\hline \multirow[t]{2}{*}{ Openness } & $0.2646 * * *$ & $0.1448 * *$ & 0.0930 & 0.1467 & 0.0346 & $0.2405 * * *$ \\
\hline & $(0.0941)$ & $(0.0738)$ & $(0.1163)$ & $(0.1239)$ & $(0.0462)$ & $(0.0546)$ \\
\hline \multirow[t]{2}{*}{ ApprecREER } & 0.3186 & $0.4231 * *$ & 0.1814 & $0.5213^{*}$ & -0.0328 & $0.4347 * * *$ \\
\hline & $(0.4025)$ & $(0.1703)$ & $(0.2252)$ & $(0.3033)$ & $(0.0625)$ & $(0.1641)$ \\
\hline \multirow[t]{2}{*}{ ExchRateFlex } & & 0.0251 & -0.0170 & -0.0239 & -0.0056 & -0.0082 \\
\hline & & $(0.0161)$ & $(0.0217)$ & $(0.0237)$ & $(0.0057)$ & $(0.0164)$ \\
\hline \multirow[t]{2}{*}{ YrBefElection } & -0.0071 & -0.0256 & -0.0098 & -0.0021 & -0.0033 & -0.0233 \\
\hline & $(0.0195)$ & $(0.0214)$ & $(0.0249)$ & $(0.0245)$ & $(0.0097)$ & $(0.0192)$ \\
\hline \multirow[t]{2}{*}{ RightGov } & 0.0272 & $-0.0803 * * *$ & $-0.0924 * * *$ & -0.0382 & -0.0357 & $-0.0680 * * *$ \\
\hline & $(0.0211)$ & $(0.0275)$ & $(0.0267)$ & $(0.0264)$ & $(0.0218)$ & $(0.0219)$ \\
\hline \multirow[t]{2}{*}{ MajorityGov } & $-0.1614 * * *$ & 0.0521 & -0.0248 & $-0.1080 * * *$ & $0.0313^{*}$ & 0.0058 \\
\hline & $(0.0329)$ & $(0.0328)$ & $(0.0283)$ & $(0.0318)$ & $(0.0166)$ & $(0.0210)$ \\
\hline \multirow[t]{2}{*}{ NGovChanges } & -0.0182 & $-0.0334 * *$ & $-0.0497 * * *$ & $-0.0502 * * *$ & -0.0174 & $-0.0363 * *$ \\
\hline & $(0.0189)$ & $(0.0168)$ & $(0.0173)$ & $(0.0170)$ & $(0.0115)$ & $(0.0156)$ \\
\hline \multirow[t]{2}{*}{$C B I$} & $-0.2829 * *$ & $-0.1544 *$ & $-0.2491 * *$ & $-0.1513 * *$ & $-0.4946^{* *}$ & $-0.1586 * *$ \\
\hline & $(0.1323)$ & $(0.0862)$ & $(0.1065)$ & $(0.0713)$ & $(0.2411)$ & $(0.0718)$ \\
\hline \multirow[t]{2}{*}{$M U$} & & & $0.2432 * * *$ & $0.1620 * *$ & & $0.2141 * * *$ \\
\hline & & & $(0.0706)$ & $(0.0651)$ & & $(0.0635)$ \\
\hline \multirow[t]{2}{*}{$G F C$} & & & & & & 0.0381 \\
\hline & & & & & & $(0.0261)$ \\
\hline \#Observations & 500 & 2443 & 2651 & 1967 & 684 & 3157 \\
\hline \#Countries & 12 & 35 & 45 & 31 & 14 & 47 \\
\hline \#Episodes & 20 & 64 & 72 & 52 & 20 & 88 \\
\hline $\log \mathrm{L}$ & -134.8 & -974.0 & -935.5 & -653.9 & -212.3 & -1195.3 \\
\hline SBIC & 350.5 & 2057.2 & 1989.2 & 1421.6 & 516.1 & 2519.6 \\
\hline McFadden- $\mathrm{R}^{2}$ & 0.387 & 0.111 & 0.112 & 0.139 & 0.300 & 0.133 \\
\hline
\end{tabular}

Notes: See Tables 1-4. Estimations considering Gourinchas et al. (2001) criteria with standard deviation threshold equal to 1.5. The number of credit boom episodes is reported at the bottom of the table for each group of countries. A fixed effects logit is used in all estimations. Separate estimations for countries in the Eurozone monetary union (MU) and the others (non-MU) are provided in columns 1 and 2, respectively. In columns 3-5 are reported the results for the period before the recent Global Financial Crisis (GFC), i.e. before 2007q4. The estimation reported in column 6 includes a dummy variable that takes the value of one in the GFC period and after (i.e. 2007q4-2016q4); and 0 for the period before the GFC. 


\section{ANNEX}

Table A1: Descriptive statistics for the episodes and duration of credit booms

\begin{tabular}{lccccc}
\hline & \#Spells & Mean & St.Dev. & Min. & Max. \\
\hline All countries (67) & 220 & 8.04 & 5.82 & 1 & 32 \\
Developed countries (36) & 96 & 8.53 & 6.77 & 1 & 32 \\
Developing countries (31) & 124 & 7.66 & 4.94 & 1 & 27 \\
\hline
\end{tabular}

Notes: This table reports the number of episodes/spells (\#Spells), the mean duration (Mean), the standard deviation (St.Dev.), the minimum (Min.) and the maximum (Max.) duration for credit booms. The data are quarterly and comprises 67 countries over the period 1975q1-2016q4. Credit booms are identified using the works of Gourinchas et al. (2001) and Barajas et al. (2009). A credit boom takes place when the deviation of the ratio of credit to GDP from its trend exceeds 1.5 times of its standard deviation or the (year-on-year) growth in the credit-GDP ratio exceeds 20 percent.

Developed countries: Australia, Austria, Belgium, Bulgaria, Canada, Croatia, Cyprus, Czech Rep., Denmark, Estonia, Finland, France, Germany, Greece, Hungary, Iceland, Ireland, Italy, Japan, Latvia, Lithuania, Luxembourg, Malta, Netherlands, New Zealand, Norway, Poland, Portugal, Romania, Slovak Republic, Slovenia, Spain, Sweden, Switzerland, United Kingdom, United States.

Developing/Emerging countries: Argentina, Armenia, Bolivia, Brazil, Chile, Colombia, Costa Rica, Dominican Rep., Ecuador, El Salvador, India, Indonesia, Israel, Kenya, Korea Republic, Malaysia, Mexico, Morocco, Panama, Paraguay, Peru, Philippines, Russian Fed., South Africa, Sri Lanka, Taiwan, Thailand, Turkey, Ukraine, Uruguay, Venezuela.

Table A2. Descriptive statistics for the variables and countries used in the estimations

\begin{tabular}{|c|c|c|c|c|c|}
\hline Variable & Obs. & Mean & Std. Dev. & Min. & Max. \\
\hline CreditBoom & 3935 & 0.24 & 0.43 & 0 & 1 \\
\hline TotCapInflows & 3883 & 0.19 & 1.05 & -7.96 & 19.22 \\
\hline CapInflowsFDI & 3884 & 0.06 & 0.41 & -1.11 & 15.45 \\
\hline CapInflowsPI & 3884 & 0.06 & 0.53 & -9.04 & 12.14 \\
\hline CapInflowsOI & 3883 & 0.06 & 0.35 & -5.55 & 8.81 \\
\hline Credit/Deposits & 3935 & 5.96 & 7.47 & 0.28 & 105.88 \\
\hline Credit/GDP & 3935 & 2.81 & 17.78 & 0.01 & 576.82 \\
\hline RealCredit/pop & 3935 & 8.63 & 32.58 & 0.00 & 354.60 \\
\hline IRspread & 3933 & 6.27 & 8.12 & -17.12 & 121.00 \\
\hline LendRate & 3933 & 13.34 & 12.29 & 0.29 & 176.37 \\
\hline DepositsRate & 3933 & 7.07 & 6.69 & 0.03 & 85.23 \\
\hline RealGDPgr & 3934 & 3.13 & 3.20 & -14.81 & 14.04 \\
\hline Inflation & 3935 & 5.90 & 7.43 & -3.82 & 101.55 \\
\hline CurrAccount & 3935 & -1.26 & 5.31 & -25.55 & 17.47 \\
\hline Openness & 3935 & 0.73 & 0.41 & 0.16 & 3.58 \\
\hline ApprecREER & 3888 & 0.00 & 0.06 & -0.65 & 0.41 \\
\hline ExchRateFlex & 3935 & 2.36 & 1.13 & 1 & 6 \\
\hline ExchRateFlexF & 3935 & 8.06 & 4.11 & 1 & 15 \\
\hline Debt & 3840 & 48.15 & 28.04 & 3.66 & 219.77 \\
\hline GovBS & 3827 & -2.51 & 4.11 & -15.29 & 18.70 \\
\hline ElectionQtr & 3935 & 0.07 & 0.25 & 0 & 1 \\
\hline RightGov & 3237 & 0.45 & 0.50 & 0 & 1 \\
\hline CentreGov & 3237 & 0.12 & 0.33 & 0 & 1 \\
\hline LeftGov & 3237 & 0.42 & 0.49 & 0 & 1 \\
\hline MajorityGov & 3760 & 0.69 & 0.46 & 0 & 1 \\
\hline SPMajGov & 3760 & 0.20 & 0.40 & 0 & 1 \\
\hline CoalMajGov & 3760 & 0.49 & 0.50 & 0 & 1 \\
\hline NGovChanges & 3863 & 1.51 & 0.77 & 0 & 5 \\
\hline PartyTenure & 3472 & 22.68 & 28.29 & 1 & 260 \\
\hline GovStability & 3633 & 8.13 & 1.72 & 1 & 12 \\
\hline$C B I$ & 3932 & 0.59 & 0.24 & 0.13 & 0.90 \\
\hline CBI_unwgted & 3932 & 0.58 & 0.22 & 0.08 & 0.89 \\
\hline CBI_H\&B_wgted & 3701 & 0.60 & 0.23 & 0.17 & 0.96 \\
\hline CBI_H\&B_unwgted & 3701 & 0.59 & 0.24 & 0.12 & 0.96 \\
\hline CBā̄kRate & 3935 & 7.56 & 7.21 & 0.10 & 71.10 \\
\hline$M 2 g r$ & 2329 & 3.34 & 5.29 & -33.49 & 76.18 \\
\hline$M U$ & 3935 & 0.13 & 0.34 & 0 & 1 \\
\hline BankCrisis & 3934 & 0.05 & 0.21 & 0 & 1 \\
\hline
\end{tabular}


Table A3. List of countries used in the estimations, credit booms date and duration

\begin{tabular}{|c|c|c|c|c|c|c|c|}
\hline Country & Begin & End & Duration & Country & Begin & End & Duration \\
\hline Argentina & $1997 q 1$ & $1999 q 1$ & 9 & Japan & $1998 \mathrm{q} 2$ & $2001 q 3$ & 14 \\
\hline Armenia & $1999 q 2$ & $2000 q 4$ & 7 & Korea Republic & $2002 q 2$ & $2004 q 1$ & 9 \\
\hline Armenia & $2004 q 3$ & $2009 q 1$ & 19 & Korea Republic & $2008 \mathrm{q} 1$ & $2009 q 2$ & 6 \\
\hline Australia & $1989 q 1$ & $1991 \mathrm{q} 2$ & 10 & Latvia & $1997 q 2$ & 1999q1 & 8 \\
\hline Australia & $2007 q 4$ & $2009 q 2$ & 7 & Latvia & $2000 \mathrm{q} 3$ & $2008 \mathrm{q} 2$ & 32 \\
\hline Austria & $2005 q 2$ & $2006 q 3$ & 6 & Latvia & $2009 q 3$ & $2010 q 3$ & 5 \\
\hline Bolivia & $1990 q 2$ & $1995 q 1$ & 20 & Lithuania & $1998 q 2$ & $1999 q 3$ & 6 \\
\hline Bolivia & $1996 q 4$ & $1998 \mathrm{q} 4$ & 9 & Lithuania & $2002 q 3$ & $2008 \mathrm{q} 4$ & 26 \\
\hline Brazil & $2006 q 3$ & $2008 \mathrm{q} 4$ & 10 & Luxembourg & $2005 \mathrm{q} 2$ & $2006 q 4$ & 7 \\
\hline Bulgaria & $2001 \mathrm{q} 4$ & $2009 q 3$ & 32 & Luxembourg & $2007 q 4$ & $2008 \mathrm{q} 4$ & 5 \\
\hline Canada & $1981 q 2$ & $1982 q 3$ & 6 & Malta & $2000 q 2$ & $2002 q 1$ & 8 \\
\hline Canada & $2001 q 4$ & $2003 q 2$ & 7 & Malta & $2008 q 2$ & $2009 q 2$ & 5 \\
\hline Canada & $2006 q 3$ & $2006 q 4$ & 2 & Mexico & 1989q1 & $1995 \mathrm{q} 3$ & 27 \\
\hline Chile & $2007 q 3$ & $2009 q 1$ & 7 & Netherlands & $1996 q 1$ & $1998 \mathrm{q} 1$ & 9 \\
\hline Colombia & $1997 \mathrm{q} 3$ & $1999 q 2$ & 8 & Norway & $1984 q 4$ & $1991 \mathrm{q} 2$ & 27 \\
\hline Colombia & $2006 q 3$ & $2009 q 1$ & 11 & Norway & $1997 q 3$ & $1998 \mathrm{q} 4$ & 6 \\
\hline Costa Rica & $1998 \mathrm{q} 1$ & $2001 \mathrm{q} 1$ & 13 & Norway & $2006 \mathrm{q} 2$ & $2006 q 4$ & 3 \\
\hline Costa Rica & $2007 q 1$ & $2009 q 3$ & 8 & Paraguay & $2001 \mathrm{q} 2$ & $2003 q 1$ & 8 \\
\hline Croatia & $1997 q 4$ & $1998 \mathrm{q} 4$ & 5 & Paraguay & $2007 q 3$ & $2009 q 2$ & 8 \\
\hline Croatia & $2001 q 1$ & $2003 q 3$ & 11 & Paraguay & $2010 q 2$ & $2010 q 4$ & 3 \\
\hline Cyprus & $2000 q 1$ & $2001 \mathrm{q} 4$ & 8 & Peru & $1995 q 3$ & 1999q1 & 15 \\
\hline Cyprus & $2007 q 1$ & $2008 \mathrm{q} 2$ & 6 & Philippines & $1983 q 2$ & $1984 q 3$ & 6 \\
\hline Czech Republic & $1996 \mathrm{q} 2$ & $1998 \mathrm{q} 3$ & 10 & Philippines & $1993 q 2$ & $1998 \mathrm{q} 3$ & 22 \\
\hline Czech Republic & $2005 q 2$ & $2008 q 3$ & 14 & Poland & $2006 q 3$ & $2009 q 2$ & 12 \\
\hline Denmark & $1986 q 3$ & $1986 q 4$ & 2 & Portugal & 1997q1 & $2003 q 1$ & 25 \\
\hline Denmark & $1987 q 4$ & $1990 \mathrm{q} 4$ & 13 & Portugal & $2007 q 4$ & $2009 q 1$ & 6 \\
\hline Denmark & $2000 \mathrm{q} 3$ & $2000 q 4$ & 2 & Romania & $1998 \mathrm{q} 3$ & $1999 q 1$ & 3 \\
\hline Ecuador & $1993 q 3$ & $1995 q 4$ & 10 & Romania & $2001 q 4$ & $2009 q 2$ & 31 \\
\hline Ecuador & $1997 q 3$ & $1998 \mathrm{q} 4$ & 6 & Russian Federation & $1998 \mathrm{q} 3$ & $2002 q 2$ & 16 \\
\hline Ecuador & $2001 \mathrm{q} 1$ & $2002 q 2$ & 6 & Russian Federation & $2006 q 1$ & $2009 q 2$ & 14 \\
\hline Estonia & $1996 \mathrm{q} 2$ & $1998 \mathrm{q} 2$ & 9 & Slovak Republic & $1996 q 2$ & $1998 \mathrm{q} 2$ & 9 \\
\hline Estonia & $2005 q 3$ & $2009 q 1$ & 15 & Slovenia & $2004 q 1$ & $2009 q 2$ & 22 \\
\hline Finland & $1989 q 1$ & $1993 \mathrm{q} 1$ & 17 & South Africa & 2001q2 & $2002 q 1$ & 4 \\
\hline Finland & $2007 q 4$ & $2008 \mathrm{q} 4$ & 5 & South Africa & $2006 \mathrm{q} 1$ & $2009 q 1$ & 13 \\
\hline France & $1978 \mathrm{q} 1$ & $1979 q 4$ & 8 & Spain & $2006 q 4$ & $2009 q 2$ & 11 \\
\hline France & $2007 q 3$ & $2008 \mathrm{q} 4$ & 6 & Sweden & 2001q1 & $2003 q 3$ & 11 \\
\hline Germany & $2000 q 1$ & $2001 \mathrm{q} 4$ & 8 & Switzerland & $1999 q 3$ & 2001q1 & 7 \\
\hline Germany & $2008 \mathrm{q} 4$ & $2009 q 3$ & 4 & Switzerland & $2006 \mathrm{q} 3$ & $2008 \mathrm{q} 3$ & 9 \\
\hline Greece & $2007 q 3$ & $2008 \mathrm{q} 4$ & 7 & Thailand & $1995 \mathrm{q} 4$ & $1999 q 2$ & 15 \\
\hline Greece & $2010 q 2$ & $2011 \mathrm{q} 1$ & 4 & Thailand & $2010 q 2$ & $2010 q 3$ & 2 \\
\hline Hungary & $2000 q 1$ & $2001 q 1$ & 5 & Ukraine & $1999 q 3$ & $2004 q 3$ & 20 \\
\hline Hungary & $2003 q 2$ & $2004 q 3$ & 6 & Ukraine & $2005 q 3$ & $2009 q 3$ & 17 \\
\hline Hungary & $2007 q 4$ & $2009 q 1$ & 6 & United Kingdom & $2007 q 4$ & $2009 q 1$ & 6 \\
\hline Iceland & $1997 \mathrm{q} 4$ & $2001 q 2$ & 15 & United States & $1978 \mathrm{q} 3$ & $1980 \mathrm{q} 1$ & 7 \\
\hline Iceland & $2004 q 1$ & $2008 \mathrm{q} 3$ & 19 & United States & $1988 q 4$ & $1990 \mathrm{q} 4$ & 9 \\
\hline Indonesia & $1986 q 4$ & $1991 \mathrm{q} 2$ & 19 & United States & $2007 q 2$ & $2009 q 1$ & 8 \\
\hline Indonesia & $1997 q 3$ & $1998 \mathrm{q} 4$ & 6 & & & & \\
\hline Italy & $1991 \mathrm{q} 4$ & $1993 q 4$ & 9 & & & & \\
\hline Italy & $1999 q 1$ & $2001 \mathrm{q} 4$ & 12 & & & & \\
\hline Italy & $2010 \mathrm{q} 2$ & $2011 \mathrm{q} 1$ & 4 & Average duration & & & 10.5 \\
\hline
\end{tabular}

Notes: This list only reports those countries and events of credit booms that are used in the estimations; when the political and institutional variables are added, Armenia, Indonesia, Lithuania and Switzerland are excluded from the sample due to lack of data or variability for those variables. Credit booms identified using Gourinchas et al. (2001) and Barajas et al. (2009) criterion (see notes on Tables A1 and A2). 